Article

\title{
Unlocking Value Creation Using an Agritourism Business Model
}

\author{
Laura Broccardo *, Francesca Culasso and Elisa Truant \\ Department of Management, University of Turin, 10100 Turin, Italy; francesca.culasso@unito.it (F.C.); \\ elisa.truant@unito.it (E.T.) \\ * Correspondence: laura.broccardo@unito.it
}

Received: 28 July 2017; Accepted: 24 August 2017; Published: 12 September 2017

\begin{abstract}
Agritourism has achieved a greater importance in the last decade, but despite this relevance, the definition is not aligned everywhere, depending on the contingency variables of the context in which agritourism is located. This paper aims at analyzing the business model's key success factors of Italian agritourism by studying their structural, social and economic features, integrated with a sustainability approach. The empirical analysis is based on a sample of agritourism, located in an Italian region. The empirical results show relevant and useful elements to support the sustainable development of agritourism business models in Italy, linking theory, policy and practices. Indeed, these results, together with others related to the economic dimension of the farms, their specialization, and the characteristics of the farmers make it possible to argue that there are common elements, which offer potential for agritourism. In addition, it was possible to identify two different models of agritourism. Agritourism can open new horizons in rural sustainable development, with possible beneficial effects on the environment, society, agricultural heritage and economic growth. In particular, regional policy developers should take into consideration these elements in order to direct correctly efforts. The research shows also some interesting theoretical implications as it contributes to enrich the literature on this particular kind of business model. At the same time, it helps family owners to increase the overall understanding of their agritourism, in order to finalize adequate planning and communication.
\end{abstract}

Keywords: agritourism; business models; BM; Business Model Innovation; BMI; key success factors; Italy; sustainability; rural development

\section{Introduction}

This paper illustrates the results of research conducted on Italian agritourism, which is here considered as a particular form of innovation in the more traditional agricultural Business Model (BM). Agritourism is a complex and differentiated phenomenon [1] that has been widespread worldwide since the early twentieth century [2,3] and it is affected by the socio-economic characteristics of each individual territory, landscape and regulations. In Italy, agritourism was imported during the 1960s by agricultural entrepreneurs who travelled around the world (especially in Austria and France), and they immediately developed this in a country in which rural outmigration was particularly intense and many abandoned buildings were available for this utilisation [4]. Consequently, it has gained economic and social relevance, with an increasing diffusion in all regions [5]. Italian agritourism represents a truly unique case in the international scene, because the national legislation regulates it in a particular way in comparison to other forms of rural tourism worldwide [6,7]. Indeed, Italian agritourism can only be managed by the farmer and his family, and the tourist activities of the farm must be connected and complementary to agriculture, which remains the fundamental activity of the farm $[4,8]$. In addition, the predominance of agricultural activity is explicitly determined in terms of number of working hours and not in terms of income [6,7], as occurs in other countries. 
Agritourism can be seen as an innovative and diversification strategy for farms, by including recreation and leisure activities for tourists, with many economic and non-economic benefits for farmers, visitors and communities [9]. Visitors can enjoy and reinforce the atmosphere of the agricultural life, while the agricultural entrepreneurs have the opportunity to increase their income providing touristic services, remaining in the business and creating additional employment. The agricultural heritage is preserved, and the economic situation of local communities is improved. In other words, agritourism can be considered as "a sustainable strategy: in its stated objectives, it promotes the conservation of a broadly conceived rural environment through its socioeconomic development" [4]. Agritourism is perceived as the "missing link in a quality territorial system that integrates agricultural, tourist, environmental, cultural and historic resources" [4]. It likely represents "the most radical product innovation that has ever concerned the national agriculture" and has different characteristics in comparison with other more traditional forms of agricultural farms [7]. Agritourism offers good opportunities for business and employment, conserving and developing rural landscape and biodiversity [7], while answering to a tourist demand. In other words, agritourism can be considered as a peculiar form of innovation in the more traditional agricultural Business Model (BM). This is because a BM represents a general and holistic understanding of how an organization creates value through its activities and processes, involving several actors in its value chain and creating various interdependencies and dynamics with stakeholders [10,11]. Business Model Innovation (BMI) can refer to both the development of new BMs for start-ups and to the reconfiguration of existing BMs [12]. In our research, we refer to this second interpretation of BMI when analyzing the agritourism phenomenon. Indeed, agritourism can be interpreted as a reconfiguration of the existing model of agricultural farms to a new one.

Usually companies and institutions develop new ideas and value creation through their existing business models, investing extensive resources in research activities, and the results they reach are often not so satisfactory if they do not invest any effort in changing the business models, through which new ideas and technologies will pass. Indeed, the same idea or technology that passes through different BMs can lead to different results. Therefore, it might be appropriate for companies and institutions to develop the capability to innovate their BMs [13].

A certain part of the literature on BMI has emphasized the importance of the innovation in terms of a firm's success, while a new literature strand has investigated the relevance of the BMI in terms of sustainability, considering the consequences of BMI in terms of corporate social and environmental impact [12]. This means that an innovative and sustainable BM should try to align the firms' profitability with economic and non-economic benefits for society and the local community. In our work, agritourism is interpreted as a BMI aimed at generating sustainability. In these terms, if agritourism is meant as a BMI towards sustainability, it is important to study this phenomenon through the BM's key success factors.

As observed by Choo [14], agritourism research still needs a framework for systematically studying and creating knowledge. Indeed, it is necessary to observe the management, planning, and policy implications, since agritourism studies and related researches are still in the early stage of development and there is great scope for theoretical advances [14]. Based on this evidence and trying to answer to a general call for more research directed at identifying the drivers of the agritourism success [7], the present article aims to analyze the features of agritourism in order to provide a more holistic picture about these kinds of businesses. It tries to capture the key elements in their value creation process and to improve the understanding of an innovative and sustainable BM. To analyze the key success factors at the centre of agritourism-sustainable BMs, we used the Osterwalder [15] approach, which explains a BM through 9 components, underlining the sustainable features adopting the Schaltegger [16] approach. We based our empirical analysis on a sample of 110 companies from Piedmont, an Italian region located in the North-West. The agritourism business is particularly interesting for the Italian economy due to its continued growth, and the main concentration of 
agritourism farms is in the Italian northern regions [17]. To conduct our research, we adopted a questionnaire as the main tool of analysis, and the following research questions have been formulated:

- $\quad$ R.Q. 1: what are the key success factors of Italian agritourism BMs that enable a sustainable value creation?

- $\quad$ R.Q. 2: is there any correlation among these key factors affecting the agritourism BMs?

- $\quad$ R.Q. 3: is it possible to identify different groups of BMs inside the sample?

The rest of the paper is structured as follows: the next section illustrates the theoretical background of the agritourism phenomenon and the BMI framework, which informs our research under a sustainability perspective. The methodological design is presented in Section 3, while Section 4 offers a reading of the empirical results achieved and the discussion. In the last section, conclusions and future research are presented.

\section{Theoretical Background}

\subsection{Agritourism Overview}

Despite the relevance of agritourism around the world, an agreed upon definition of this phenomenon does not exist in international tourism research. The lack of an unambiguous definition and the presence of cognitive differences about the meaning and features of agritourism create some difficulties in conducting research, especially in the academic literature, and in favouring the development of a homogeneous field of studies [18].

In particular, the inconsistencies in defining agritourism in literature are correlated to four ontological issues [3], that are: (i) the identification of an appropriate setting; (ii) the typology of experiences by customers in agritourism; (iii) the kind of activities that agritourism should offer; and (iv) the clear definition of the term "tourism" in the concept of "agritourism".

With respect to the first issue, it is unclear if agritourism can be carried out only on a farm or also in any other agricultural establishment, such as ranches, nurseries and others, and if it is possible to expand the setting to off-farm facilities, such as markets in which the agricultural products of the farmers are sold. The difficulty in identifying a proper setting for agritourism may depend on different meanings that are present in various regulations about the concept of "farm". In the E.U., a farm is a single managed agricultural entity that is also engaged in non-agricultural activities [19], while in U.S., the definition is strictly correlated with the amount of revenues that come from the production or distribution of agricultural products [20]. In any case, the academic literature has recently separated the agritourism settings from the concept of "rurality", and the "rural tourism" is something different from agritourism.

Concerning the second issue, it is ambiguous if the farm or any other agricultural establishment should be considered working or if it can be accepted as a non-working farm. There are few researchers $[18,21]$ that consider an "authentic" experience in agritourism demonstrated by agricultural activities, and if not real, through non-working models.

The third issue depends on different government policies around the world [4]. Sometimes they include in the definition of agritourism activities hospitality and lodging, education, food services, event programming, recreational activities, etc. In other cases, these kinds of services are excluded (e.g., Australia). For example, in the Italian National Framework for Agritourism [22], hospitality is included in the agritourism activities.

Finally, the fourth issue is about the ambiguous meaning of the term "tourism" in the word "agritourism". In particular, for some authors it refers to the need for travel, and the term agritourism implies a sort of farm-stay or any kind of accommodation [4].

Despite the ontological issues above mentioned, in the last few years several scholars $[3,18,23]$ tried to develop a shared definition of agritourism, basing it on empirical researches. In particular, Arroyo [3] investigated the preferences expressed by various agritourism stakeholders (farmers, residents and Extension Faculty) and, as a result, they formulated the following definition of agritourism: 
"Farming-related activities carried out on a working farm or other agricultural settings for entertainment or education purposes" [3]. This definition includes agritourism products based either on a working farm or on a different agricultural setting. Consistent with this definition, Flanigan [23] suggests the existence of the following typologies of agritourisms: (i) agritourism based on a working farm; (ii) agritourism not based on a working farm.

However, the limitation of these studies is that their empirical analysis is restricted to some specific geographical area, and the agritourism definition may depend on the geographical/contextual locality identified [18]. In our study, the Italian agritourism based on a working farm is taken into consideration, as the Italian legislation states that hospitality activities, which are not based on a working farm, cannot be defined as agritourism activities. Indeed, under a normative perspective, the E.U. refers to agritourism in generic terms as a particular "form of holiday which is carried out in rural areas" [7] and this approach implies limited involvement of farms in carrying out agritourism in Europe. On the contrary, the meaning of the term "agritourism" in Italy is strictly defined by the current regulation (Law n. 96/2006) as "the hospitality activities practiced by agricultural entrepreneurs [ ... ] through the use of their firms, in connection with the farming activities, the forestry-related activities, and livestock activities", with the limitation that "agricultural activities prevail [over the agritourism activities]". In other words, Italian agritourism has distinctive features with respect to other European countries, thanks to the particular national legislation.

Lupi [7] identified the rational foundations of the Italian legislation, which pursued ambitious goals related to (i) economic issues, by integrating farmers' revenues and by promoting local products; (ii) socio-cultural issues, by consolidating the relations between the city and the country-side, and by preserving local traditions; (iii) environmental issues, by protecting the environment and the landscape; (iv) occupational issues, by creating new job opportunities, especially in the marginal areas, with the aim of limiting the exodus of the young and female labour force.

The goals identified by Lupi [7] underline the sustainability aims of this kind of business. Indeed, agritourism is a significant part of the sustainable expansion and country revolution. Furthermore, the management of agritourism businesses not only contains all fundamentals of traditional farm management, but also requires farm operators to manage the intangible resources in a sustainable way [24].

Considering Lupi [7], it emerges that agritourism can be considered as a particular form of the more traditional BMs operating in the agriculture context. In particular, Lupi [7] suggests that: "it could be interesting to identify the drivers that mostly boost agritourism income. In other words, through the analysis of economic, environmental and social variables, representing internal factors (i.e., direct sales of farm products, educational activities, organic certifications, forest cover), it will be possible to identify the determinants that mostly contribute to the development of agritourism and that could be used by policy maker as instruments for sustainable rural development".

Following this vision and trying to cover this suggested gap, we deepen the analysis of the key elements for value creation in this kind of business, adopting the Osterwalder's [15] framework on BMs, integrated within a sustainability perspective [16].

\subsection{BMs and Sustainability in Agritourism: Theoretical Framework}

The BM is often studied without an explicit definition of the concept itself. Sometimes studies do not define the concept at all, others define or conceptualize the BM by enumerating its main components, and others refer to the work of other scholars in defining the concept itself [25].

Due to this confusion and the risk in research dispersion, Zott [25] summarized some of the most prevalent definitions, underlining that the BM concept has been employed mainly in trying to address or explain, among the others, strategic issues, such as value creation, competitive advantage, and firm performance.

Following this approach, the BM is an additional unit of analysis for researchers and it is nestled between the business and its network of exchange partners [12]. To be more precise, the value 
generation mainly occurs in a value network [10,11], which includes suppliers, partners, distribution channels and coalitions that extend the company's resources. In a BM there is a so-called "focal" organisation that manages value-added relations with a plethora of actors, who become strategic in the dynamic and interdependent process of value creation for the whole community. The collaboration between firms and other key stakeholders is very important [26] and "value is no longer created by firms acting autonomously, but by firms acting together with parties external to the firm through informal arrangements or formal alliances" [27].

The framework of Osterwalder [15] and of Osterwalder and Pigneur [28,29] decomposes a BM into 9 components that are worthy of being mapped and analysed, in order to individualise the key success factors of the BM itself.

This framework is useful to help both academics and practitioners to understand deeply the context in which a BM works. In particular, it suggests studying BMs in a more holistic perspective. The 9 key value factors are:

1. key activities: the core processes and the corresponding characteristics, both intra- and inter-organizations, that will guarantee the achievement of better outcome performances;

2. partner network: the main actors involved in BMs and the characteristics of their reciprocal partnerships;

3. key resources: the human, physical and monetary resources that are necessary to adequately support processes and networks;

4. cost structure: the structure of costs and the optimal efficiency level. Indeed, the cost minimization behaviour is relevant for firms, in order to achieve profitability;

5. revenue flows: the structure of revenues and the main sources, the volumes to quantify them, the targeted selling prices and the targeted selling mix to maximise profitability;

6. distribution channels: how to deliver goods and services to customers;

7. value proposition: the reason for which customers should purchase goods and service of a value chain, instead of others. The needs and the features of clients' behaviour are to be studied, since they influence their purchasing choices;

8. client segments: how a customer base is segmented into groups of people that are similar in their behaviours, especially for the marketing purposes;

9. client relationships: how long-term relationships are protected and maintained between suppliers and their customers, which are relevant to generate revenues in the future.

Focusing on agritourism BMs and their value creation, some authors emphasize the perceived value by the customers adopting a five dimensional model based on functional, convenience, emotional, social and educational components [30]. Other authors focus on benefits perceived by the agritourism provider [9], showing that agritourism should be considered not only in terms of increased profits but also as a marketing tool.

A strand of the literature also categorized agritourism focusing on different goals, identified in profitability, customer orientation, role of the family and interests of the farm operator such as the enjoyment of the rural life style [9,31-34].

Furthermore, a part of the literature discusses three external environment elements, that are community, economic status, and organizational support [35-37], as core factors for these kinds of organizations. Doh et al. [38] proposed a model based on perceived external environment factors, internal conditions, managerial behaviour and business performance, mainly financial ones.

Despite this evidence, rural tourism constitutes a valuable tool for the sustainable development of many rural areas [30] and makes a positive contribution to the culture of host communities [39], and it sensitises communities to the cultural and economic value of their landscape and habitats. Hence, rural tourism has become a powerful tool in diversifying activities in rural areas, providing a sustainable alternative to traditional resort tourism $[40,41]$. 
Recently, scholars have been attracted by BMs represented by new organizational architectures that are oriented not only to profitability purposes, but also to solve social problems and sustainability issues [12].

Based on this last consideration, we integrated the Ostewalder's BM approach $[15,28,29]$ with the Schaltegger's et al. [16] considerations to design the Business Model for Sustainability. Following Schaltegger et al. [16], a business model for sustainability helps describing, analysing, managing and communicating (i) a company's sustainable value proposition to its customers and all other stakeholders; (ii) determines how it creates and delivers this value; (iii) and how it captures economic value while maintaining or regenerating natural, social and economic capital beyond its organizational boundaries.

The definitions of sustainable tourism vary based on the multidimensionality of both sustainability and tourism terms [42,43], and it is influenced also by the political and environmental approach. Furthermore, there is common consideration that tourism activities are sustainable only when they are economically viable without destroying the environment and the social wellbeing [44].

In the case of agritourism, it is possible to translate sustainable principles into the ability of preserving the farmer's historic ties to the land and traditional knowledge, employing sustainable agricultural practices, increasing farm revenues and profits, sustaining the landscape, habitats and soil productivity. Consequently, it is possible to preserve the family farmland for future generations and sustain rural economies [31,39,45-47]. Agritourism farms approach sustainability producing multiple environmental, sociocultural and economic benefits for their farms, households and even society [32].

This means that the sustainable value proposition must provide value in both ecological or social and economic terms, also through offering products and services in line with this concept. In addition, the business infrastructure must be rooted in principles of sustainable supply chain management, the customer interface must enable close relationships with customers and other stakeholders, to take responsibility for production and consumption systems (instead of simply "selling stuff"), and the financial model should distribute economic costs and benefits equitably among actors involved [48].

Even if previous studies on sustainable tourism have focused on understanding the attitudes and perceptions of local residents, tourists and other stakeholders [45,49-52], analysing the agritourism BM framework shows a lack of studies that try to capture the key factors for value creation in agritourism, including the three sustainability dimensions [32]:

- $\quad$ economic, e.g., increased revenues for agritourism farms can boost local economies through increased sales taxes, generation of local employment and stimulation of local businesses;

- $\quad$ sociocultural, e.g., agritourism has been suggested as a means to provide employment for family members, preserving the farmland for future generations, or as a plan for farm succession;

- environmental, e.g., preservation of the rural landscapes and natural habitats, offering ecotourism activities.

Due to this gap in the literature research, this article tries to deepen the sustainability perspective of the Italian agritourism BMs.

\section{Methodological Design}

The research focuses on agritourism located in the Piedmont, a North-West Italian region. Italy is a regionally administered country, with a general national legislative corpus for agritourism, but in which each region decides, based on the agricultural characteristics of the area, to what extent the general criteria stated in national laws should apply to local needs [8]. The agritourism business is particularly interesting for the Italian economy due to its continued growth. In particular, in the North of Italy there is a high concentration of agritourism farms, providing accommodation (41\%); in addition, $45 \%$ of agritourism providing food services is located in the Italian northern regions [17]. The choice of the Piedmont region is driven by the relevance of this geographical area, as the Piedmont is one pre-eminent region in terms of agritourist supply and which has a strong attraction for tourists 
such as natural resources, countryside and food and wine. Moreover, the Piedmont is at the top position in Italian ranking for number of agritourism businesses and the first region for didactical agri-farms [17]. Furthermore, the Piedmont territory of Langhe-Roero and Monferrato became a World Heritage Site of UNESCO in 2014.

A questionnaire-based survey was conducted among a sample of 110 Italian agritourism businesses located in the Piedmont Region. The sampling list was drawn from the regional lists of Italian agritourism farms. In detail, the initial sample of 1030 agritourism farms represented the whole regional universe and the questionnaire was sent by e-mail to all the agritourism businesses located in the Region. The respondents were selected using the database provided by the same Region and were sent a description of the research aims, a compilation guide and a link to an online questionnaire. The compilation period was about 3 months, with several requests made by telephone in order to solicit the answers. The final sample was composed of 110 agritourism businesses, which corresponded to a response rate of $11 \%$; this compares favourably with rates reported in previous online surveys among tourism and hospitality operators [53].

The questionnaire included questions in the following areas of research: company profile, key financial data, type of services offered, type of customers, involvement of family/external managers, and key activities. Answers included both opened and closed questions, as well as a five-point Likert scale. In addition, free spaces were given to the operators to write any additional comments about their experience with agritourism.

The questionnaire method was chosen because it allows researchers to obtain a significant amount of data that can be used for statistical investigation. Based on the methodology followed by different studies on this topic [3], the data were analysed using SPSS software and evidence was studied using descriptive and inferential statistics. Specifically, the Pearson coefficient was used as it enables, better than other types of correlations, to measure the relationship between linearly related variables.

\section{The Sample Features}

The sample is composed of 110 predominantly "young" agritourism businesses as they are mainly managed by the first generation of owners. The next Table 1 shows the number of generations involved with agritourism.

Table 1. Generations involved in agritourism.

\begin{tabular}{cc}
\hline Number of Generations Involved in Agritourism Activities & Percentage \\
\hline 1 & $51 \%$ \\
2 & $40 \%$ \\
3 & $9 \%$ \\
Total & $100 \%$ \\
\hline
\end{tabular}

With respect to the agritourism features, the role of the family members in agritourism was also investigated, and the results are shown in Table 2.

Table 2. Role of family members.

\begin{tabular}{cc}
\hline Role Covered by Family Members in Agritourism Management & Percentage \\
\hline Management and coordination activities & $11 \%$ \\
Operating activities & $15 \%$ \\
Both & $75 \%$ \\
Total & $100 \%$ \\
\hline
\end{tabular}

As it emerges from Table 2, families with both managerial and operating roles characterize the great majority of agritourism businesses. 
Moreover, it is possible to affirm that, referring to the gender diversity of family and non-family members, the women involvement in running agritourism slightly predominates (see Table 3 ).

Table 3. Gender diversity.

\begin{tabular}{cc}
\hline Does Female Component Predominate? & Percentage \\
\hline No & $45 \%$ \\
Yes & $55 \%$ \\
Total & $100 \%$ \\
\hline
\end{tabular}

\section{Findings and Discussion}

In order to answer the first R.Q.: what are the key success factors of Italian agritourism BMs that enable a sustainable value creation?, we used the questionnaire responses and depicted the 9 key success factors identified by Osterwalder [15] and by Osterwalder and Pigneur [28,29], integrated within the sustainability dimension through the Schaltegger et al. [16] approach.

\subsection{Key Activities}

The next Table 4 shows the activities carried out by the agritourism businesses of the sample.

Table 4. Main agritourism activities.

\begin{tabular}{lcc}
\hline \multicolumn{1}{c}{ Main Agritourism Activities } & Percentage & Ranking \\
\hline Accomodation & $85 \%$ & 1 \\
Additional activities (harvesting grapes, fruits, etc.) & $26 \%$ & 6 \\
Camping & $6 \%$ & 8 \\
Catering \& Restaurants & $54 \%$ & 3 \\
Excursions and nature trails & $34 \%$ & 4 \\
Learning farm activities & $25 \%$ & 7 \\
Others (excursions and guided tours, learning & $32 \%$ & 5 \\
laboratories, wellness, and agricultural production) & $80 \%$ & 2 \\
Sales of own agricultural products & $80 \%$ & \\
\hline
\end{tabular}

Analysing this table, it emerges that the most widespread activities are those linked with the accommodation and sales of one's own agricultural products. The majority of the samples also offer catering and restaurant services, while camping is not particularly widespread.

The activities considered as particularly relevant in agritourism in this sample, especially for the value creation in their business, are represented by:

- the offering of complementary products and services (agricultural products, cooking courses, cultural events, agri-camping, swimming pools, and didactical farms);

- restaurants and catering.

In particular, $47.64 \%$ stated availability to address more investments to support the offering of complementary products/services, while $8.19 \%$ indicated support for restaurants and catering services. Furthermore, they affirmed the activities considered strategic for the agritourism business are constantly monitored under the point of view of cost ( $87.50 \%$ of the sample) and quality $(95.74 \%$ of the sample).

Under a sustainability perspective, a strong link with the land and the natural environment emerges, also highlighted by the offering of one's own agricultural products, excursions and nature trails, learning farm activities and additional activities such as harvesting grapes and fruits. 


\subsection{Partner Network}

A total of $98 \%$ of the sample declared not to have key supplier partners; according to the Italian agritourism laws, they have to internally produce the products destined for restaurants or for sale. Under a sustainability perspective, this aspect indicates a very short supply chain, while, adopting a particular point of view, key partners can be considered the employees working in agritourism, as will be analysed in the following section.

\subsection{Key Resources}

The resources considered strategic by the respondents in order to run the agritourism business are represented by the involved family and not family employees and the required financial resources to support agritourism investments. The next Table 5 shows the number of family members involved in the agritourism activity.

Table 5. Number of family members involved in agritourism.

\begin{tabular}{cc}
\hline Number of Family Members Involved in Agritourism & Percentage \\
\hline 0 & $1 \%$ \\
1 & $25 \%$ \\
2 & $43 \%$ \\
3 & $15 \%$ \\
4 & $11 \%$ \\
5 & $5 \%$ \\
Total & $100 \%$ \\
\hline
\end{tabular}

A total of $43 \%$ of respondents declared that two family members are involved in running the business, both at the managerial and operational levels. A total of $31 \%$ of agritourism businesses is run by more than two family members, while one quarter of agritourism is run by one family member. These data show good involvement and presence of the family in managing the agritourism.

Under a sustainability perspective, this result highlights the increase of wellbeing and the safeguard of the cultural heritage of rural families, carrying on the traditions and laying the foundation for job creation for future generations of the family.

With respect to the number of employees not belonging to the family, the results are shown in the following table (Table 6).

Table 6. Number of employees not belonging to the family-owner.

\begin{tabular}{cc}
\hline Number of Employees Not Belonging to the Family-Owner & Percentage \\
\hline 0 & $54 \%$ \\
1 & $16 \%$ \\
2 & $15 \%$ \\
3 & $7 \%$ \\
4 & $4 \%$ \\
6 & $2 \%$ \\
7 & $1 \%$ \\
10 & $1 \%$ \\
11 & $1 \%$ \\
Total & $100 \%$ \\
\hline
\end{tabular}

The majority of agritourism (54\%) does not involve "external" personnel, while a number of non-family employees, between one and three, characterizes $38 \%$ of the sample. The maximum number of external employees involved does not exceed 11 units ( $1 \%$ of the sample). Matching the results of Tables 5 and 6 , it emerges that there is a limited dimension of these organizations in terms of people involved. 
Under a sustainability perspective, it has to be underlined how, despite the limited opportunities of employment due to the small average dimension of agritourism, the high involvement of family members confirm the previous evidence and the effort by the family in passing on the business and consequently creating value for the future generations.

After investigating the human key resources, the financing sources used by the agritourism businesses of the sample were analysed, and the results are shown in Table 7.

Table 7. Financing sources.

\begin{tabular}{cc}
\hline Financing Sources & Percentage \\
\hline Bank loans & $32 \%$ \\
Governmental grants & $1 \%$ \\
Own investments & $66 \%$ \\
Own investments and bank loans & $1 \%$ \\
Total & $100.00 \%$ \\
\hline
\end{tabular}

The previous table highlights the considerable involvement of the family from a financial point of view, as the key financial resources are mainly represented by financing of the owners, while the bank loans are widespread across $33 \%$ of the sample. Only $1 \%$ declared the use public sources.

Under a sustainability perspective, there emerges a strong self-financing in covering the new agritourism investments, and this aspect can create a virtuous circle due to the reinvestment of the gained earnings internally.

\subsection{Cost Structure}

The next table focuses on the cost structure of agritourism of the last three years (2013-2015). Firstly, the weight of the total costs on the turnover was investigated (Table 8).

Table 8. Annual average costs over the last three years.

\begin{tabular}{cc}
\hline Annual Average Costs over the Last Three Years Represent & Percentage \\
\hline Less than the 50\% of turnover & $27 \%$ \\
More than the 70\% of turnover & $15 \%$ \\
Between $50 \%$ and $60 \%$ of turnover & $31 \%$ \\
Between $60 \%$ and $70 \%$ of turnover & $27 \%$ \\
Total & $100 \%$ \\
\hline
\end{tabular}

Table 8 shows how in the majority of the sample (58\%), the percentage of annual average costs is between $50 \%$ and $70 \%$ of the company's turnover, while for $27 \%$, the cost weight is lower than $50 \%$ of the turnover.

Subsequently, the cost composition analysis was deepened. From the questionnaire, it emerged how the cost structure is represented mainly by the cost of personnel, the raw materials, and the depreciation of fixed assets. Table 9 shows this cost structure composition.

Analysing the data included in Table 9 shows that:

- $\quad$ in $63 \%$ of agritourism businesses, the cost of personnel represents between $10 \%$ and $20 \%$ of total costs, confirming family management;

- in $64 \%$ of agritourism businesses, the cost of raw materials represents between $20 \%$ and $30 \%$ of costs;

- the depreciation cost, compared to the previous two categories, is more distributed, highlighting a generally higher incidence. 
Under a sustainability perspective, the ability of agritourism to optimize the direct cost is evident, especially by self-producing the raw material goods, preserving the natural environment and the wellbeing of the local community.

Table 9. Breakdown of costs.

\begin{tabular}{cccc}
\hline $\begin{array}{c}\text { Percentage of Costs } \\
\text { Relative to the Total }\end{array}$ & $\begin{array}{c}\text { Cost of Personnel } \\
\text { (\% of Respondents) }\end{array}$ & $\begin{array}{c}\text { Raw Materials (\% of } \\
\text { Respondents) }\end{array}$ & $\begin{array}{c}\text { Depreciation (\% of } \\
\text { Respondents) }\end{array}$ \\
\hline $0 \%$ & $0 \%$ & $0 \%$ & $9 \%$ \\
$10 \%$ & $46 \%$ & $10 \%$ & $15 \%$ \\
$20 \%$ & $17 \%$ & $36 \%$ & $21 \%$ \\
$30 \%$ & $10 \%$ & $28 \%$ & $15 \%$ \\
$40 \%$ & $10 \%$ & $14 \%$ & $11 \%$ \\
$50 \%$ & $10 \%$ & $7 \%$ & $13 \%$ \\
$60 \%$ & $5 \%$ & $4 \%$ & $12 \%$ \\
$70 \%$ & $1 \%$ & $2 \%$ & $4 \%$ \\
$80 \%$ & $0 \%$ & $0 \%$ & $1 \%$ \\
Total & $100.00 \%$ & $100.00 \%$ & $100.00 \%$ \\
\hline
\end{tabular}

\subsection{Revenue Flows}

The next table shows the average turnover declared by agritourism businesses.

Table 10 shows a significant prevalence of small businesses, with the average turnover of the last three years (2013-2015) lower than 100,000 euros. Only $2 \%$ of the sample declared a turnover higher than 300,000 euros. This result confirms the limited development of agritourism in terms of revenues flows.

Table 10. Average turnover.

\begin{tabular}{lc}
\hline \multicolumn{1}{c}{ Average Turnover of Agritourism over the Last 3 Years } & Total \\
\hline Less than $100,000 €$ & $88 \%$ \\
Between $100,000 €$ and $200,000 €$ & $10 \%$ \\
More than $300,000 €$ & $2 \%$ \\
Total & $100 \%$ \\
\hline
\end{tabular}

Under a sustainability perspective, the small dimension could represent an advantage as it enables preservation of cultural and product heritage. Indeed, the exploitation of the local resources to achieve turnover is not so greedy as in a large industrial-scale production. In addition, the scarce presence of agritourism with a turnover greater than 300,000 euro underlines a limited ambition to increase the dimension, confirming the will to focus more on quality than quantity, also preserving the territory.

\subsection{Distribution Channels}

The distribution channel is predominantly direct ( $80 \%$ of the sample), because agritourism offers services and sells products without intermediation of customers. However, when the absorption capacity is not sufficient ( $20 \%$ of the sample), the businesses use a fragmented distribution channel represented by distributors or retail shops. The choice of the distribution channel is strongly represented by the type of final product (food or beverage).

Under a sustainability perspective, this aspect again shows a short supply chain, offering "farm to table" products.

\subsection{Value Proposition}

Within the questionnaire, we also investigated the perceived needs and the features behind the customer behaviour choice (Table 11). 
Table 11. Main value proposition elements.

\begin{tabular}{lcc}
\hline \multicolumn{1}{c}{ Main Value Proposition Elements } & Percentage & Ranking \\
\hline Compliance with quality standards and certification & $75 \%$ & 3 \\
Genuine products and strong link with the territory & $92 \%$ & 1 \\
Maintaining a high and consistent product quality & $88 \%$ & 2 \\
Maintaining strong ties with clientele & $64 \%$ & 4 \\
Keeping abreast of market trends & $32 \%$ & 5 \\
\hline
\end{tabular}

Analysing the previous table, it emerges that the elements perceived as the most important to address customer's behaviour are the offer of genuine products, ability to valorise the link with the territory, followed by the high quality of the same.

Moreover, in order to improve the business, $45 \%$ of the agritourim businesses declared to have finalized activities to reorganize the company's structure from the point of view of activities and of the role of employees.

Under a sustainability perspective, the will to preserve cultural and product heritage, protecting the environment, is again observed.

The main benefits achieved thanks to these reorganizational interventions are described in the following table (Table 12).

Table 12. Main reorganization benefits.

\begin{tabular}{ccc}
\hline Main Benefits Resulting from Reorganization & Percentage & Ranking \\
\hline Turnover increase & $52 \%$ & 3 \\
Cost savings & $65 \%$ & 2 \\
Customer satisfaction & $77 \%$ & 1 \\
\hline
\end{tabular}

The main benefits resulting from the reorganization are recognized in an increase in efficiency turnover and customer satisfaction.

Under a sustainability perspective, this aspect shows a cost saving implementing recycling programs.

\subsection{Client Segments}

The next tables (Tables 13 and 14) show the customer composition by age and nationality. We firstly distinguished three clusters by age: the first one is represented by young (18-35 years) customers; the second one by families (with parents and children) and the third one by customers over 65 .

Table 13. Customer composition by age.

\begin{tabular}{cccc}
\hline Customer Composition by Age & Young (18-35 Years) & Families & Over 65 \\
\hline $0 \%$ & $3 \%$ & $1 \%$ & $5 \%$ \\
$10 \%$ & $15 \%$ & $5 \%$ & $11 \%$ \\
$20 \%$ & $26 \%$ & $9 \%$ & $28 \%$ \\
$30 \%$ & $31 \%$ & $15 \%$ & $16 \%$ \\
$40 \%$ & $10 \%$ & $25 \%$ & $19 \%$ \\
$50 \%$ & $6 \%$ & $21 \%$ & $5 \%$ \\
$60 \%$ & $1 \%$ & $11 \%$ & $5 \%$ \\
$70 \%$ & $0 \%$ & $5 \%$ & $2 \%$ \\
$80 \%$ & $1 \%$ & $2 \%$ & $2 \%$ \\
$90 \%$ & $0 \%$ & $2 \%$ & $0 \%$ \\
$100 \%$ & $1 \%$ & $1 \%$ & $0 \%$ \\
Not answered & $5 \%$ & $4 \%$ & $6 \%$ \\
Total & $100 \%$ & $100 \%$ & $100 \%$ \\
\hline
\end{tabular}


Table 14. Customer composition by nationality.

\begin{tabular}{ccc}
\hline Customer Composition by Nationality & Italian Customers & Foreign Customers \\
\hline $10 \%$ & $9 \%$ & $9 \%$ \\
$20 \%$ & $4 \%$ & $10 \%$ \\
$30 \%$ & $8 \%$ & $13 \%$ \\
$40 \%$ & $8 \%$ & $5 \%$ \\
$50 \%$ & $14 \%$ & $16 \%$ \\
$60 \%$ & $16 \%$ & $14 \%$ \\
$70 \%$ & $5 \%$ & $8 \%$ \\
$80 \%$ & $13 \%$ & $8 \%$ \\
$90 \%$ & $10 \%$ & $4 \%$ \\
$100 \%$ & $9 \%$ & $9 \%$ \\
Not answered & $5 \%$ & $5 \%$ \\
Total & $100 \%$ & $100 \%$ \\
\hline
\end{tabular}

Analysing the previous table, it emerges that around $30 \%$ of the sample works with $30 \%$ of young customers, while $25 \%$ of the sample works with $40 \%$ of families and $28 \%$ of the sample works with $20 \%$ of customers over 65 years.

The next table (Table 14) shows the customer composition differentiated between Italian and foreign customers.

The previous table shows different classes-Italian and foreign-of customers declared by the sample. For example, $14 \%$ of the sample works with $50 \%$ of Italian customers, another $14 \%$ works with $60 \%$ of foreign customers and $5 \%$ of the total sample works with $70 \%$ of Italian clients and $40 \%$ of foreign clients.

Under the sustainability perspective, no particular patterns emerge.

\subsection{Client Relationships}

With the questionnaire, the perception of the importance of maintaining and improving relations with customers was also investigated. A total of $96 \%$ declared they invested in activities to increase customer loyalty, while $4 \%$ did not invest in them.

Furthermore, we identified the main tools applied to increase customer loyalty (Table 15).

Table 15. Tools to maintain and improve customers' loyalty.

\begin{tabular}{ccc}
\hline Tools to Maintain and Improve Customers' Loyalty & Percentage & Ranking \\
\hline Discounts & $75 \%$ & 1 \\
Promotional activities & $45 \%$ & 3 \\
Compliments & $73 \%$ & 2 \\
Service customization & $30 \%$ & 5 \\
Quality & $43 \%$ & 4 \\
\hline
\end{tabular}

From Table 15, it emerges how discounts, compliments and promotional activities are some of the most used tool to maintain and improve customer loyalty.

Under a sustainability perspective, the capability to improve customer loyalty emerges, as well as communicating value and raising awareness for the safeguard of the environment. Furthermore, it should also be highlighted that a loyal customer can increase the wellbeing, not only of the family behind the agritourism, but also of the local community.

Answering the second R.Q. 2: is there any correlation among the key success factors affecting the agritourism BMs?, we analyzed the results of the Pearson correlations (Table 16), taking into consideration the main variables previously described and characterizing the key factors of the Osterwalder and Pigneur [28,29] BM. 
Table 16. Pearson correlations.

\begin{tabular}{|c|c|c|c|c|c|c|c|c|c|c|c|c|c|c|c|}
\hline Correlations (Pearson) & $\begin{array}{l}\text { Italian } \\
\text { Customers }\end{array}$ & $\begin{array}{c}\text { Foreign } \\
\text { Customers }\end{array}$ & $\begin{array}{c}\text { Young } \\
\text { Customers }\end{array}$ & $\begin{array}{l}\text { "Families" } \\
\text { Customers }\end{array}$ & $\begin{array}{l}\text { Over } 65 \\
\text { Customers }\end{array}$ & $\begin{array}{c}\text { Family } \\
\text { Members } \\
\text { Involved in } \\
\text { Agritourism }\end{array}$ & $\begin{array}{c}\text { Role of } \\
\text { Family } \\
\text { Members } \\
\text { within } \\
\text { Agritourism }\end{array}$ & $\begin{array}{l}\text { Number of } \\
\text { Generation } \\
\text { Involved in } \\
\text { Agritourism }\end{array}$ & $\begin{array}{l}\text { Gender } \\
\text { Diversity }\end{array}$ & $\begin{array}{l}\text { Non-Family } \\
\text { Members } \\
\text { Involved in } \\
\text { Agritourism }\end{array}$ & $\begin{array}{c}\text { Average } \\
\text { Turnover } \\
\text { of the Last } \\
\text { Three } \\
\text { Years }\end{array}$ & $\begin{array}{c}\text { Average } \\
\text { Annual } \\
\text { Costs of the } \\
\text { Last Three } \\
\text { Years }\end{array}$ & $\begin{array}{l}\text { Financing } \\
\text { Sources }\end{array}$ & $\begin{array}{c}\text { Investment } \\
\text { in Activities } \\
\text { to Increase } \\
\text { Customer } \\
\text { Loyalty }\end{array}$ & $\begin{array}{l}\text { Reorganization } \\
\text { Activities }\end{array}$ \\
\hline $\begin{array}{c}\text { Italian Customers } \\
\mathrm{N}\end{array}$ & $\begin{array}{c}1 \\
110\end{array}$ & & & & & & & & & & & & & & \\
\hline $\begin{array}{c}\text { Foreign customers } \\
\mathrm{N}\end{array}$ & $\begin{array}{c}-0.703 \text { ** } \\
110\end{array}$ & $\begin{array}{c}1 \\
110\end{array}$ & & & & & & & & & & & & & \\
\hline $\begin{array}{c}\text { Young customers } \\
\mathrm{N}\end{array}$ & $\begin{array}{l}0.257^{* *} \\
110\end{array}$ & $\begin{array}{l}-0.108 \\
110\end{array}$ & $\begin{array}{c}1 \\
110\end{array}$ & & & & & & & & & & & & \\
\hline $\begin{array}{l}\text { "Families" customers } \\
\text { N }\end{array}$ & $\begin{array}{l}0.204^{*} \\
110\end{array}$ & $\begin{array}{c}0.036 \\
110\end{array}$ & $\begin{array}{l}-0.260 \text { ** } \\
110\end{array}$ & $\begin{array}{c}1 \\
110\end{array}$ & & & & & & & & & & & \\
\hline $\begin{array}{c}\text { Over } 65 \text { customers } \\
\mathrm{N}\end{array}$ & $\begin{array}{l}-0.103 \\
110\end{array}$ & $\begin{array}{l}0.240^{*} \\
110\end{array}$ & $\begin{array}{l}-0.262 * * \\
110\end{array}$ & $\begin{array}{c}-0.412 \text { ** } \\
110\end{array}$ & $\begin{array}{c}1 \\
110\end{array}$ & & & & & & & & & & \\
\hline $\begin{array}{c}\text { Family members involved } \\
\text { in agritourism } \\
\mathrm{N}\end{array}$ & $\begin{array}{c}0.023 \\
110\end{array}$ & $\begin{array}{c}0.051 \\
110\end{array}$ & $\begin{array}{c}-0.011 \\
110\end{array}$ & $\begin{array}{c}-0.075 \\
110\end{array}$ & $\begin{array}{c}0.075 \\
110\end{array}$ & $\begin{array}{c}1 \\
110\end{array}$ & & & & & & & & & \\
\hline $\begin{array}{l}\text { Role of family members } \\
\text { within agritourism } \\
\mathrm{N}\end{array}$ & $\begin{array}{c}-0.076 \\
110\end{array}$ & $\begin{array}{c}0.046 \\
110\end{array}$ & $\begin{array}{c}-0.016 \\
110\end{array}$ & $\begin{array}{c}0.183 \\
110\end{array}$ & $\begin{array}{c}-0.194 * \\
110\end{array}$ & $\begin{array}{c}0.150 \\
110\end{array}$ & $\begin{array}{c}1 \\
110\end{array}$ & & & & & & & & \\
\hline $\begin{array}{c}\text { Number of generation } \\
\text { involved in agritourism } \\
\mathrm{N}\end{array}$ & $\begin{array}{c}0.187 \\
110\end{array}$ & $\begin{array}{c}-0.135 \\
110\end{array}$ & $\begin{array}{c}0.006 \\
110\end{array}$ & $\begin{array}{c}-0.009 \\
110\end{array}$ & $\begin{array}{c}0.163 \\
110\end{array}$ & $\begin{array}{c}0.430 * * \\
110\end{array}$ & $\begin{array}{c}-0.118 \\
110\end{array}$ & $\begin{array}{c}1 \\
110\end{array}$ & & & & & & & \\
\hline $\begin{array}{c}\text { Gender diversity } \\
\text { N }\end{array}$ & $\begin{array}{c}-0.035 \\
110 \\
\end{array}$ & $\begin{array}{c}-0.002 \\
110 \\
\end{array}$ & $\begin{array}{c}0.003 \\
110\end{array}$ & $\begin{array}{c}-0.132 \\
110\end{array}$ & $\begin{array}{c}0.083 \\
110\end{array}$ & $\begin{array}{c}-0.036 \\
110\end{array}$ & $\begin{array}{c}-0.075 \\
110\end{array}$ & $\begin{array}{c}0.150 \\
110\end{array}$ & $\begin{array}{c}1 \\
110\end{array}$ & & & & & & \\
\hline $\begin{array}{c}\text { Non-family members } \\
\text { involved in agritourism } \\
\mathrm{N}\end{array}$ & $\begin{array}{c}0.166 \\
110\end{array}$ & $\begin{array}{c}-0.103 \\
110\end{array}$ & $\begin{array}{c}0.116 \\
110\end{array}$ & $\begin{array}{c}-0.034 \\
110\end{array}$ & $\begin{array}{c}0.037 \\
110\end{array}$ & $\begin{array}{c}0.235^{*} \\
110\end{array}$ & $\begin{array}{c}-0.019 \\
110\end{array}$ & $\begin{array}{c}0.006 \\
110\end{array}$ & $\begin{array}{c}-0.189 \\
* \\
110\end{array}$ & $\begin{array}{c}1 \\
110\end{array}$ & & & & & \\
\hline $\begin{array}{c}\text { Average turnover of the } \\
\text { last three years } \\
\mathrm{N}\end{array}$ & $\begin{array}{c}0.167 \\
110\end{array}$ & $\begin{array}{l}-0.145 \\
110\end{array}$ & $\begin{array}{c}0.114 \\
110\end{array}$ & $\begin{array}{c}-0.004 \\
110\end{array}$ & $\begin{array}{c}-0.028 \\
110\end{array}$ & $\begin{array}{c}0.134 \\
110\end{array}$ & $\begin{array}{c}0.032 \\
110\end{array}$ & $\begin{array}{c}-0.111 \\
110\end{array}$ & $\begin{array}{c}-0.148 \\
110\end{array}$ & $\begin{array}{c}0.762 \text { ** } \\
110\end{array}$ & $\begin{array}{c}1 \\
110\end{array}$ & & & & \\
\hline $\begin{array}{l}\text { Average annual costs of } \\
\text { the last three years } \\
\mathrm{N}\end{array}$ & $\begin{array}{c}0.148 \\
110\end{array}$ & $\begin{array}{c}-0.081 \\
110\end{array}$ & $\begin{array}{c}0.147 \\
110\end{array}$ & $\begin{array}{c}0.033 \\
110\end{array}$ & $\begin{array}{c}-0.053 \\
110\end{array}$ & $\begin{array}{c}0.099 \\
110\end{array}$ & $\begin{array}{c}0.114 \\
110\end{array}$ & $\begin{array}{c}0.153 \\
110\end{array}$ & $\begin{array}{c}-0.029 \\
110\end{array}$ & $\begin{array}{c}0.320^{* *} \\
110\end{array}$ & $\begin{array}{c}0.250 \text { ** } \\
110\end{array}$ & $\begin{array}{c}1 \\
110\end{array}$ & & & \\
\hline $\begin{array}{c}\text { Financing sources } \\
\mathrm{N}\end{array}$ & $\begin{array}{c}0.111 \\
110\end{array}$ & $\begin{array}{l}-0.107 \\
110\end{array}$ & $\begin{array}{l}-0.014 \\
110\end{array}$ & $\begin{array}{l}-0.081 \\
110\end{array}$ & $\begin{array}{c}0.019 \\
110\end{array}$ & $\begin{array}{c}-0.035 \\
110\end{array}$ & $\begin{array}{c}-0.034 \\
110\end{array}$ & $\begin{array}{l}-0.168 \\
110\end{array}$ & $\begin{array}{c}0.026 \\
110\end{array}$ & $\begin{array}{c}0.036 \\
110\end{array}$ & $\begin{array}{c}0.121 \\
110\end{array}$ & $\begin{array}{l}-0.065 \\
110\end{array}$ & $\begin{array}{c}1 \\
110\end{array}$ & & \\
\hline $\begin{array}{l}\text { Investment in activities to } \\
\text { increase customer loyalty } \\
\mathrm{N}\end{array}$ & $\begin{array}{c}-0.081 \\
110\end{array}$ & $\begin{array}{c}0.055 \\
110\end{array}$ & $\begin{array}{c}-0.362 * * \\
110\end{array}$ & $\begin{array}{c}0.114 \\
110\end{array}$ & $\begin{array}{c}0.134 \\
110\end{array}$ & $\begin{array}{c}0.085 \\
110\end{array}$ & $\begin{array}{c}-0.040 \\
110\end{array}$ & $\begin{array}{c}0.015 \\
110\end{array}$ & $\begin{array}{c}-0.080 \\
110\end{array}$ & $\begin{array}{c}0.119 \\
110\end{array}$ & $\begin{array}{c}0.067 \\
110\end{array}$ & $\begin{array}{c}0.062 \\
110\end{array}$ & $\begin{array}{c}0.134 \\
110\end{array}$ & $\begin{array}{c}1 \\
110\end{array}$ & \\
\hline $\begin{array}{c}\text { Reorganization activities } \\
\mathrm{N}\end{array}$ & $\begin{array}{c}0.120 \\
110\end{array}$ & $\begin{array}{l}-0.056 \\
110\end{array}$ & $\begin{array}{c}0.095 \\
110\end{array}$ & $\begin{array}{l}-0.089 \\
110\end{array}$ & $\begin{array}{c}0.156 \\
110\end{array}$ & $\begin{array}{c}0.089 \\
110\end{array}$ & $\begin{array}{c}0.115 \\
110\end{array}$ & $\begin{array}{c}0.022 \\
110\end{array}$ & $\begin{array}{c}0.083 \\
110\end{array}$ & $\begin{array}{c}0.163 \\
110\end{array}$ & $\begin{array}{l}0.201 * \\
110\end{array}$ & $\begin{array}{l}0.017 \\
110\end{array}$ & $\begin{array}{c}0.058 \\
110\end{array}$ & $\begin{array}{c}0.076 \\
110\end{array}$ & $\begin{array}{c}1 \\
110\end{array}$ \\
\hline
\end{tabular}


Based on the Pearson correlation, it is possible to highlight some interesting results. Positive and strong correlations involve:

- $\quad$ young customers, with an age between 18 and 35 years old, of Italian nationality;

- the number of generation involved in agritourism with the presence of family members;

- $\quad$ average turnover of the last three years with non-family members involved;

- $\quad$ average costs of the last three years with non-family members involved;

- $\quad$ average costs of the last three years with the average turnover of the last three years.

Some moderate correlations are also present between (i) customers over 65 and foreign customers and (ii) reorganization activities and average turnover of the last three years.

These strong and moderate correlations, previously listed, highlight that, at the basis of agritourism value proposition, there are some emerging key elements.

In particular, from the customer perspective, it is possible to suggest that the key factors are based on Italian young customers and families and foreign customers over 65.

A relevant result that characterizes the analyzed agritourism shows that an increase in the turnover is linked to an increase in non-family members involved in running the business.

In addition, the regression result was calculated; a significant result refers to the link between the presence of non-family members and the average turnover of the last three years, with an $R^{2}$ of 0.59 and $\beta$ of 0.744 .

Based on the results of Table 17, there is an increase in average turnover influenced by an increase in non-family members within company staff.

Table 17. Regression.

\begin{tabular}{cccccc}
\hline Model & R & R-Squared & R-Squared Adjusted & Beta & Sign. \\
\hline 1 & 0.774 & 0.599 & 0.592 & 0.744 & 0.000 \\
\hline
\end{tabular}

Despite the previous evidence about the strong involvement of the family within the business, this result suggests that, if agritourism aims at expanding and growth, they should involve external personnel, not belonging to the family.

Answering the last research question-R.Q. 3: is it possible to identify different peculiar groups of BMs inside the sample? - the agritourism businesses were clustered in "New Generation" (NG), when these businesses were in their first stage of generational succession and in "Old Generation" (OG), when the businesses were in their second or third generation. More specifically, NG represents $50.91 \%$ of the sample, while OG represents $49.09 \%$. From the clustering, two different BMs emerged and their peculiarities are described below, according to the 9 key success factors identified by the Osterwalder [15] and by Osterwalder and Pigneur [28,29] model, integrated with the sustainability dimension of Schaltegger et al. [16].

\subsection{Key Activities in NG and OG}

The next Table 18 shows the activities carried out through agritourism, clustered in NG and OG.

Analysing the table, it emerges that NG and OG are similar in some key activities for value creation, such as:

- Accommodation;

- Camping;

- Excursions and nature trails;

- Others;

while some differences, relevant for value creation, are shown in: 
- $\quad$ Additional activities;

- $\quad$ Catering and Restaurant;

- $\quad$ Learning farm activities;

- $\quad$ Sales of own agricultural products.

In both NG and OG the accommodation activity is the most relevant for value creation, while camping is not particularly significant. On the contrary, catering \& restaurant, learning farm activities, and sales of own agricultural products are considered more important in OG than in NG.

Table 18. Main NG and OG agritourism activities.

\begin{tabular}{ccccc}
\hline Main Activities of Agritourism & \multicolumn{2}{c}{ NG } & \multicolumn{2}{c}{ OG } \\
\cline { 2 - 5 } & $\%$ & Ranking & $\%$ & Ranking \\
\hline Accomodation & $42.73 \%$ & 1 & $42.73 \%$ & 1 \\
Additional activities (harvesting grapes, fruits, etc.) & $14.55 \%$ & 6 & $11.82 \%$ & 4 \\
Camping & $3.64 \%$ & 8 & $2.73 \%$ & 5 \\
Catering \& Restaurants & $23.64 \%$ & 3 & $30.00 \%$ & 2 \\
Excursions and nature trails & $18.18 \%$ & 4 & $15.45 \%$ & 3 \\
Learning farm activities & $10.00 \%$ & 7 & $15.45 \%$ & 3 \\
Others (excursions and guided tours, learning & $16.36 \%$ & 5 & $15.45 \%$ & 3 \\
laboratories, wellness, and agricultural production) & $37.27 \%$ & 2 & $42.73 \%$ & 1 \\
Sales of own agricultural products & \multicolumn{3}{c}{}
\end{tabular}

Under a sustainability perspective, there is a strong link with the land and the natural environment, especially in OG where the focus is mainly concentrated on the offering of own agricultural products and learning farm activities.

\subsection{Partner Network in NG and OG}

The features of the partner network confirmed the results previously described in the general sample. The short supply chain is confirmed when considering the sustainability perspective.

The employees, as potential partners, will be analysed in the following section.

\subsection{Key Resources in NG and OG}

Analysing the key resources, in terms of employees belonging to the family, it emerged that the number of family members increases within OG agritourism.

Table 19 shows the number of family components involved in the NG and OG agritourism activities.

Table 19. Number of family components involved in agritourism.

\begin{tabular}{ccc}
\hline $\begin{array}{c}\text { Number of Family Components } \\
\text { Involved in Agritourism }\end{array}$ & NG & OG \\
\cline { 2 - 3 } & Percentage & Percentage \\
\hline 0 & $0.91 \%$ & $0 \%$ \\
1 & $20.91 \%$ & $4.55 \%$ \\
2 & $23.64 \%$ & $19.09 \%$ \\
3 & $2.73 \%$ & $12.73 \%$ \\
4 & $1.82 \%$ & $9.09 \%$ \\
5 & $0.91 \%$ & $3.64 \%$ \\
\hline
\end{tabular}

It emerged that $89.29 \%$ of $\mathrm{NG}$ agritourism involves between 0 and 2 family members (compared to $48.16 \%$ of OG), while $51.86 \%$ of OG agritourism involves between 3 and 5 family members (compared to $10.72 \%$ of NG). 
Under a sustainability perspective, this result highlights the increase of wellbeing and the protection of the cultural heritage of rural families, especially in OG agritourism.

With respect to the number of employees not belonging to the family working within agritourism, the result between OG and NG agritourism is shown in the following Table 20.

Table 20. Number of employees not belonging to the family-owner.

\begin{tabular}{ccc}
\hline \multirow{2}{*}{$\begin{array}{c}\text { Number of Employees Not } \\
\text { Belonging to the Family-Owner }\end{array}$} & NG & OG \\
\cline { 2 - 3 } & Percentage & Percentage \\
\hline 0 & $29.09 \%$ & $24.55 \%$ \\
1 & $7.27 \%$ & $9.09 \%$ \\
2 & $7.27 \%$ & $7.27 \%$ \\
3 & $2.73 \%$ & $4.55 \%$ \\
4 & $2.73 \%$ & $0.91 \%$ \\
6 & $1.82 \%$ & - \\
7 & - & $0.91 \%$ \\
10 & - & $0.91 \%$ \\
11 & - & $0.91 \%$ \\
\hline
\end{tabular}

It can be observed that NG agritourism is more inclined to involve employees not belonging to the family, compared with OG agritourism. Indeed, $96.43 \%$ of NG agritourism involves between 0 and 4 employees not belonging to the family (compared to $94.45 \%$ for OG), and $3.57 \%$ of NG agritourism involves between 6 and 11 employees not belonging to the family (compared to $5.56 \%$ of NG).

Under a sustainability perspective, it is possible to confirm the limited employment opportunities in both NG and OG.

The financing sources used by the NG and OG agritourism are shown in the Table 21.

Table 21. Financing sources.

\begin{tabular}{ccc}
\hline \multirow{2}{*}{ Financing Sources } & NG & OG \\
\cline { 2 - 3 } & Percentage & Percentage \\
\hline Bank loans & $20 \%$ & $11.82 \%$ \\
Governmental grants & - & $0.91 \%$ \\
Own investments & $30.91 \%$ & $35.345 \%$ \\
Own investments and bank loans & - & $0.91 \%$ \\
\hline
\end{tabular}

Under a sustainability perspective, the NG propensity is greater toward bank loans, compared to the OG, which prefers own financing. Indeed, it emerges how OG agritourism prefers strong self-financing to support new agritourism investments.

\subsection{Cost Structure in NG and OG}

The next Table 22 focuses on the cost structure of NG and OG agritourism.

Table 22. Annual average costs over the last three years.

\begin{tabular}{ccc}
\hline Annual Average Costs over the & New Generation & Old Generation \\
\cline { 2 - 3 } Last Three Years Represent & Percentage & Percentage \\
\hline Less than $50 \%$ of turnover & $16.36 \%$ & $10.91 \%$ \\
Between $50 \%$ and $60 \%$ of turnover & $11.82 \%$ & $19.09 \%$ \\
Between $60 \%$ and $70 \%$ of turnover & $15.45 \%$ & $11.82 \%$ \\
More than 70\% of turnover & $7.27 \%$ & $7.27 \%$ \\
\hline
\end{tabular}


The table shows the propensity of the OG to contain costs, which is not that evident. The costs are under $60 \%$ of turnover in $61 \%$ of OG agritourism businesses ( $55.35 \%$ in NG), while they reach $60 \%$ of turnover in $44.63 \%$ of NG agritourism businesses ( $38.89 \%$ in OG).

The cost composition is quite similar in both NG and OG agritourism.

The cost structure, shown in Table 23, is mainly represented by the cost of personnel, the raw materials and the depreciation of fixed assets.

Table 23. Breakdown of costs.

\begin{tabular}{ccccccc}
\hline $\begin{array}{c}\text { Percentage } \\
\text { of Costs } \\
\text { Relative to } \\
\text { the Total }\end{array}$ & $\begin{array}{c}\text { Cersonnel (\% of } \\
\text { Pespondents) }\end{array}$ & $\begin{array}{c}\text { Raw Materials } \\
\text { (\% of } \\
\text { Respondents) }\end{array}$ & $\begin{array}{c}\text { Depreciation } \\
\text { (\% of } \\
\text { Respondents) }\end{array}$ & $\begin{array}{c}\text { Cost of } \\
\text { Personnel (\% of } \\
\text { Respondents) }\end{array}$ & $\begin{array}{c}\text { Raw Materials } \\
\text { (\% of } \\
\text { Respondents) }\end{array}$ & $\begin{array}{c}\text { Depreciation } \\
\text { (\% of } \\
\text { Respondents) }\end{array}$ \\
\hline 0 & $0.00 \%$ & $0.00 \%$ & $4.55 \%$ & $0.00 \%$ & $0.00 \%$ & $4.55 \%$ \\
$10 \%$ & $26.36 \%$ & $6.36 \%$ & $7.27 \%$ & $20.00 \%$ & $3.64 \%$ & $7.27 \%$ \\
$20 \%$ & $8.18 \%$ & $19.00 \%$ & $10.00 \%$ & $9.09 \%$ & $16.36 \%$ & $10.91 \%$ \\
$30 \%$ & $2.73 \%$ & $11.82 \%$ & $8.18 \%$ & $7.27 \%$ & $16.36 \%$ & $7.27 \%$ \\
$40 \%$ & $3.64 \%$ & $7.27 \%$ & $3.64 \%$ & $6.36 \%$ & $6.36 \%$ & $7.27 \%$ \\
$50 \%$ & $5.45 \%$ & $4.55 \%$ & $7.27 \%$ & $4.55 \%$ & $2.73 \%$ & $5.45 \%$ \\
$60 \%$ & $3.64 \%$ & $1.82 \%$ & $9.09 \%$ & $1.82 \%$ & $1.82 \%$ & $2.73 \%$ \\
$70 \%$ & $0.91 \%$ & $0.00 \%$ & $0.91 \%$ & $0.00 \%$ & $1.82 \%$ & $2.73 \%$ \\
$80 \%$ & $0.00 \%$ & $0.00 \%$ & $0.00 \%$ & $0.00 \%$ & $0.00 \%$ & $0.91 \%$ \\
\hline
\end{tabular}

From a sustainability perspective, it is confirmed, in both NG and OG, the ability to optimize the direct costs, especially by self-producing the raw material goods, preserving the natural environment and the wellbeing of the local community.

\subsection{Revenue Flows in NG and OG}

The Table 24 shows the average turnover declared by agritourism businesses.

Table 24. Average turnover.

\begin{tabular}{ccc}
\hline Average Turnover of Agritourism & NG & OG \\
\cline { 2 - 3 } over the Last 3 Years & Total & Total \\
\hline Less than $100,000 €$ & $43.64 \%$ & $44.55 \% \%$ \\
Between $100,000 €$ and $200,000 €$ & $7.27 \%$ & $2.73 \%$ \\
More than $300,000 €$ & $0.00 \%$ & $1.82 \% \%$ \\
\hline
\end{tabular}

The table shows a significant prevalence of small businesses, both in NG and OG; however, only the OG declared a turnover greater than 300,000 and more than $4.50 \%$ of NG has revenues between 100,000 and 200,000 .

Under a sustainability perspective, both NG and OG have a small dimension in turnover, and this aspect can favour cultural and product heritage, as indicated above.

\subsection{Distribution Channels in NG and OG}

The distribution channel is confirmed predominantly direct ( $80 \%$ of the sample), both in NG and OG, underlining, under a sustainability perspective, a short supply chain.

\subsection{Value Proposition in $N G$ and $O G$}

With respect to the perceived needs and the features behind the customer behaviour choices, it is possible to confirm an inclination in OG toward genuine products and a strong link with the territory, while NG is more focused on obtaining quality certifications, as shown in Table 25. 
Table 25. Main value proposition elements.

\begin{tabular}{ccccc}
\hline \multirow{2}{*}{ Main Value Proposition Elements } & \multicolumn{2}{c}{ NG } & \multicolumn{2}{c}{ OG } \\
\cline { 2 - 5 } & Percentage & Ranking & Percentage & Ranking \\
\hline Compliance with quality standards and certification & $44.65 \%$ & 2 & $30.35 \%$ & 4 \\
Genuine products and strong link with the territory & $42.20 \%$ & 3 & $49.80 \%$ & 1 \\
Maintaining a high and consistent product quality & $49.45 \%$ & 1 & $38.45 \%$ & 2 \\
Maintaining strong ties with clientele & $26.76 \%$ & 4 & $37.24 \%$ & 3 \\
Keeping abreast with market trends & $20.75 \%$ & 5 & $11.25 \%$ & 5 \\
\hline
\end{tabular}

Under a sustainability perspective, it is confirmed, especially in OG, the will to preserve cultural and product heritage, protecting the environment.

The main benefits achieved thanks to these reorganization interventions are described in the Table 26.

Table 26. Main reorganization benefits.

\begin{tabular}{ccccc}
\hline \multirow{2}{*}{$\begin{array}{c}\text { Main Benefits Resulting } \\
\text { from a Reorganization }\end{array}$} & \multicolumn{2}{c}{ New Generation } & \multicolumn{2}{c}{ Old Generation } \\
\cline { 2 - 5 } & Percentage & Ranking & Percentage & Ranking \\
\hline Turnover increase & $21.29 \%$ & 3 & $30.71 \%$ & 3 \\
Cost saving & $32.17 \%$ & 1 & $32.83 \%$ & 2 \\
Customer satisfaction & $30.33 \%$ & 2 & $46.67 \%$ & 1 \\
\hline
\end{tabular}

The NG is more inclined toward cost saving activities and customer satisfaction, while for OG, the benefits are inverted.

\subsection{Client Segments in NG and OG}

The next tables show the customer composition by age (Table 27) and nationality (Table 28) in NG and OG.

Analysing the previous table it is possible to highlight that OG agritourism, compared with NG, is more focused on families and "Over 65".

The previous table shows mainly how NG attracts more foreign customers, while OG is more oriented toward national clientele.

Table 27. Customer composition by age.

\begin{tabular}{|c|c|c|c|c|c|c|}
\hline \multirow{2}{*}{$\begin{array}{c}\text { Customer } \\
\text { Composition } \\
\text { by Age }\end{array}$} & \multicolumn{3}{|c|}{ NG } & \multicolumn{3}{|c|}{ OG } \\
\hline & $\begin{array}{c}\text { Young } \\
\text { (18-35 Years) }\end{array}$ & Families & Over 65 & $\begin{array}{c}\text { Young } \\
\text { (18-35 Years) }\end{array}$ & Families & Over 65 \\
\hline $0 \%$ & $1.25 \%$ & $0.00 \%$ & $3.00 \%$ & $1.75 \%$ & $0.91 \%$ & $2.00 \%$ \\
\hline $10 \%$ & $7.27 \%$ & $3.64 \%$ & $6.36 \%$ & $8.18 \%$ & $1.82 \%$ & $4.55 \%$ \\
\hline $20 \%$ & $13.64 \%$ & $3.64 \%$ & $20.00 \%$ & $12.73 \%$ & $4.55 \%$ & $8.18 \%$ \\
\hline $30 \%$ & $15.46 \%$ & $4.55 \%$ & $5.45 \%$ & $15.45 \%$ & $10.00 \%$ & $10.91 \%$ \\
\hline $40 \%$ & $3.64 \%$ & $11.82 \%$ & $8.18 \%$ & $6.36 \%$ & $13.64 \%$ & $10.91 \%$ \\
\hline $50 \%$ & $4.55 \%$ & $10.91 \%$ & $3.64 \%$ & $1.82 \%$ & $10.00 \%$ & $1.82 \%$ \\
\hline $60 \%$ & $0.91 \%$ & $8.18 \%$ & $0.91 \%$ & $0.00 \%$ & $2.73 \%$ & $3.64 \%$ \\
\hline $70 \%$ & $0.00 \%$ & $3.64 \%$ & $0.00 \%$ & $0.00 \%$ & $1.82 \%$ & $1.82 \%$ \\
\hline $80 \%$ & $0.91 \%$ & $0.00 \%$ & $0.91 \%$ & $0.00 \%$ & $1.82 \%$ & $0.91 \%$ \\
\hline $90 \%$ & $0.00 \%$ & $0.91 \%$ & $0.00 \%$ & $0.00 \%$ & $0.91 \%$ & $0.00 \%$ \\
\hline $100 \%$ & $0.00 \%$ & $0.00 \%$ & $0.00 \%$ & $0.91 \%$ & $0.91 \%$ & $0.00 \%$ \\
\hline
\end{tabular}


Table 28. Customer composition by nationality.

\begin{tabular}{ccccc}
\hline \multirow{2}{*}{$\begin{array}{c}\text { Customer Composition } \\
\text { by Nationality }\end{array}$} & \multicolumn{3}{c}{ NG } & \multicolumn{2}{c}{ OG } \\
\cline { 2 - 5 } & Italian Customers & Foreign Customers & Italian Customers & Foreign Customers \\
\hline $10 \%$ & $4.55 \%$ & $0.00 \%$ & $4.45 \%$ & $9.09 \%$ \\
$20 \%$ & $1.90 \%$ & $5.95 \%$ & $2.10 \%$ & $4.55 \%$ \\
$30 \%$ & $4.55 \%$ & $9.09 \%$ & $3.64 \%$ & $3.64 \%$ \\
$40 \%$ & $2.73 \%$ & $3.64 \%$ & $5.45 \%$ & $0.91 \%$ \\
$50 \%$ & $7.27 \%$ & $11.82 \%$ & $6.36 \%$ & $4.55 \%$ \\
$60 \%$ & $11.82 \%$ & $7.27 \%$ & $4.55 \%$ & $6.36 \%$ \\
$70 \%$ & $0.91 \%$ & $4.55 \%$ & $3.64 \%$ & $3.64 \%$ \\
$80 \%$ & $6.36 \%$ & $4.36 \%$ & $6.36 \%$ & $3.64 \%$ \\
$90 \%$ & $2.73 \%$ & $3.64 \%$ & $7.27 \%$ & $0.00 \%$ \\
$100 \%$ & $3.64 \%$ & $8.18 \%$ & $5.45 \%$ & $0.91 \%$ \\
Total (not including not & $46.46 \%$ & $58.50 \%$ & $49.27 \%$ & $37.29 \%$ \\
answered) & & & & \\
\hline
\end{tabular}

\subsection{Client Relationships in NG and OG}

Both NG and OG consider important the ability to maintain and improve the relations with the customer, as demonstrated by the following Table 29.

Table 29. Tools to maintain and improve customers' loyalty.

\begin{tabular}{ccccc}
\hline \multirow{2}{*}{$\begin{array}{c}\text { Tools to Maintain and Improve } \\
\text { Customers' Loyalty }\end{array}$} & \multicolumn{2}{c}{ NG } & \multicolumn{2}{c}{ OG } \\
\cline { 2 - 5 } & Percentage & Ranking & Percentage & Ranking \\
\hline Discounts & $29.24 \%$ & 2 & $45.76 \%$ & 1 \\
Promotional activities & $21.82 \%$ & 3 & $23.64 \%$ & 3 \\
Compliments & $30.34 \%$ & 1 & $42.66 \%$ & 2 \\
Service customization & $20.19 \%$ & 4 & $9.81 \%$ & 5 \\
Quality & $21.64 \%$ & 5 & $21.36 \%$ & 4 \\
\hline
\end{tabular}

The peculiarity that emerges from the two different BMs is that the NG agritourism is more inclined to offer service customization, while OG is more oriented toward traditional methods such as discount and compliments.

Under a sustainability point of view, the capability to improve the customer loyalty emerges, raising awareness for the safeguard of the environment.

Analysing the Pearson Correlation, it is possible to discover additional peculiarities of the two different BMs investigated, as illustrated in Tables 30 and 31.

In particular, in NG agritourism is positive, and strong correlations involve:

- customers over 65 and foreign customers;

- $\quad$ average turnover of the last three years with non-family members involved.

In OG agritourism, positive and strong correlations involve the average turnover of the last three years with non-family members involved, while negative and strong correlations involve:

- $\quad$ investment in activities to increase customer loyalty and young customers;

- $\quad$ customers over 65 and families;

- $\quad$ non-family members involved in agritourism and gender diversity. 
Table 30. NG Pearson correlations.

\begin{tabular}{|c|c|c|c|c|c|c|c|c|c|c|c|c|c|c|}
\hline \multicolumn{15}{|c|}{ New Generation } \\
\hline & $\begin{array}{l}\text { Italian } \\
\text { Customers }\end{array}$ & $\begin{array}{l}\text { Foreign } \\
\text { Customers }\end{array}$ & $\begin{array}{l}\text { Young } \\
\text { Customers }\end{array}$ & $\begin{array}{l}\text { "Families" } \\
\text { Customers }\end{array}$ & $\begin{array}{l}\text { Over } 65 \\
\text { Customers }\end{array}$ & $\begin{array}{c}\text { Family } \\
\text { Members } \\
\text { Involved in } \\
\text { Agritourism }\end{array}$ & $\begin{array}{c}\text { Role of } \\
\text { Family } \\
\text { Members } \\
\text { within } \\
\text { Agritourism }\end{array}$ & $\begin{array}{l}\text { Gender } \\
\text { Diversity }\end{array}$ & $\begin{array}{l}\text { Non-family } \\
\text { Members } \\
\text { Involved in } \\
\text { Agritourism }\end{array}$ & $\begin{array}{c}\text { Average } \\
\text { Turnover of } \\
\text { the Last } \\
\text { Three Years }\end{array}$ & $\begin{array}{c}\text { Average } \\
\text { Annual Costs } \\
\text { of the Last } \\
\text { Three Years }\end{array}$ & $\begin{array}{l}\text { Financing } \\
\text { Sources }\end{array}$ & $\begin{array}{c}\text { Investment } \\
\text { in Activities } \\
\text { to Increase } \\
\text { Customer } \\
\text { Loyalty }\end{array}$ & $\begin{array}{l}\text { Reorganization } \\
\text { Activities }\end{array}$ \\
\hline $\begin{array}{c}\text { Italian Customers } \\
\mathrm{N}\end{array}$ & $\begin{array}{c}1 \\
56\end{array}$ & & & & & & & & & & & & & \\
\hline $\begin{array}{c}\text { Foreign customers } \\
\mathrm{N}\end{array}$ & $\begin{array}{l}-0.694 * * \\
56\end{array}$ & $\begin{array}{c}1 \\
56\end{array}$ & & & & & & & & & & & & \\
\hline $\begin{array}{c}\text { Young customers } \\
\mathrm{N}\end{array}$ & $\begin{array}{c}0.256 \\
56\end{array}$ & $\begin{array}{c}-0.069 \\
56\end{array}$ & $\begin{array}{c}1 \\
56\end{array}$ & & & & & & & & & & & \\
\hline $\begin{array}{l}\text { "Families" customers } \\
\text { N }\end{array}$ & $\begin{array}{l}0.319^{*} \\
56\end{array}$ & $\begin{array}{l}0.009 \\
56\end{array}$ & $\begin{array}{l}-0.148 \\
56\end{array}$ & $\begin{array}{c}1 \\
56\end{array}$ & & & & & & & & & & \\
\hline $\begin{array}{c}\text { Over } 65 \text { customers } \\
\mathrm{N}\end{array}$ & $\begin{array}{l}-0.190 \\
56\end{array}$ & $\begin{array}{l}0.403 \text { ** } \\
56\end{array}$ & $\begin{array}{l}-0.198 \\
56\end{array}$ & $\begin{array}{l}-0.227 \\
56\end{array}$ & $\begin{array}{c}1 \\
56\end{array}$ & & & & & & & & & \\
\hline $\begin{array}{l}\text { Family members involved } \\
\text { in agritourism } \\
\mathrm{N}\end{array}$ & $\begin{array}{c}-0.217 \\
56\end{array}$ & $\begin{array}{c}0.102 \\
56\end{array}$ & $\begin{array}{c}-0.083 \\
56\end{array}$ & $\begin{array}{c}-0.256 \\
56\end{array}$ & $\begin{array}{c}-0.122 \\
56\end{array}$ & $\begin{array}{c}1 \\
56\end{array}$ & & & & & & & & \\
\hline $\begin{array}{l}\text { Role of family members } \\
\text { within agritourism } \\
\mathrm{N}\end{array}$ & $\begin{array}{c}0.046 \\
56\end{array}$ & $\begin{array}{c}-0.025 \\
56\end{array}$ & $\begin{array}{c}0.002 \\
56\end{array}$ & $\begin{array}{c}0.182 \\
56\end{array}$ & $\begin{array}{c}-0.171 \\
56\end{array}$ & $\begin{array}{c}0.112 \\
56\end{array}$ & $\begin{array}{c}1 \\
56\end{array}$ & & & & & & & \\
\hline $\begin{array}{c}\text { Gender diversity } \\
\mathrm{N}\end{array}$ & $\begin{array}{c}-0.141 \\
56\end{array}$ & $\begin{array}{c}0.108 \\
56\end{array}$ & $\begin{array}{l}0.078 \\
56\end{array}$ & $\begin{array}{c}-0.231 \\
56\end{array}$ & $\begin{array}{c}0.088 \\
56\end{array}$ & $\begin{array}{c}0.194 \\
56\end{array}$ & $\begin{array}{c}0.148 \\
56\end{array}$ & $\begin{array}{c}1 \\
56\end{array}$ & & & & & & \\
\hline $\begin{array}{c}\text { Non-family members } \\
\text { involved in agritourism } \\
\mathrm{N}\end{array}$ & $\begin{array}{c}0.326^{*} \\
56\end{array}$ & $\begin{array}{c}-0.207 \\
56\end{array}$ & $\begin{array}{c}0.063 \\
56\end{array}$ & $\begin{array}{c}0.151 \\
56\end{array}$ & $\begin{array}{c}-0.090 \\
56\end{array}$ & $\begin{array}{c}-0.050 \\
56\end{array}$ & $\begin{array}{c}-0.211 \\
56\end{array}$ & $\begin{array}{c}0.035 \\
56\end{array}$ & $\begin{array}{c}1 \\
56\end{array}$ & & & & & \\
\hline $\begin{array}{c}\text { Average turnover of the } \\
\text { last three years } \\
N\end{array}$ & $\begin{array}{c}0.237 \\
56\end{array}$ & $\begin{array}{c}-0.175 \\
56\end{array}$ & $\begin{array}{c}0.143 \\
56\end{array}$ & $\begin{array}{c}0.079 \\
56\end{array}$ & $\begin{array}{c}-0.152 \\
56\end{array}$ & $\begin{array}{c}-0.225 \\
56\end{array}$ & $\begin{array}{c}-0.125 \\
56\end{array}$ & $\begin{array}{c}-0.015 \\
56\end{array}$ & $\begin{array}{c}0.769^{* *} \\
56\end{array}$ & $\begin{array}{c}1 \\
56\end{array}$ & & & & \\
\hline $\begin{array}{l}\text { Average annual costs of } \\
\text { the last three years } \\
\mathrm{N}\end{array}$ & $\begin{array}{c}0.307 * \\
56\end{array}$ & $\begin{array}{c}-0.250 \\
56\end{array}$ & $\begin{array}{c}0.127 \\
56\end{array}$ & $\begin{array}{c}0.100 \\
56\end{array}$ & $\begin{array}{c}-0.088 \\
56\end{array}$ & $\begin{array}{c}-0.197 \\
56\end{array}$ & $\begin{array}{c}0.110 \\
56\end{array}$ & $\begin{array}{c}-0.058 \\
56\end{array}$ & $\begin{array}{c}0.336^{*} \\
56\end{array}$ & $\begin{array}{c}0.315 * \\
56\end{array}$ & $\begin{array}{c}1 \\
56\end{array}$ & & & \\
\hline $\begin{array}{c}\text { Financing sources } \\
\mathrm{N}\end{array}$ & $\begin{array}{l}0.170 \\
56\end{array}$ & $\begin{array}{l}-0.277^{*} \\
56\end{array}$ & $\begin{array}{l}0.070 \\
56\end{array}$ & $\begin{array}{l}-0.076 \\
56\end{array}$ & $\begin{array}{l}-0.157 \\
56\end{array}$ & $\begin{array}{c}0.093 \\
56\end{array}$ & $\begin{array}{l}-0.007 \\
56\end{array}$ & $\begin{array}{c}-0.029 \\
56\end{array}$ & $\begin{array}{c}0.168 \\
56\end{array}$ & $\begin{array}{c}0.151 \\
56\end{array}$ & $\begin{array}{l}-0.023 \\
56\end{array}$ & $\begin{array}{c}1 \\
56\end{array}$ & & \\
\hline $\begin{array}{l}\text { Investment in activities to } \\
\text { increase customer loyalty } \\
\text { N }\end{array}$ & $\begin{array}{c}-0.029 \\
56\end{array}$ & $\begin{array}{c}-0.010 \\
56\end{array}$ & $\begin{array}{c}-0.235 \\
56\end{array}$ & $\begin{array}{c}0.010 \\
56\end{array}$ & $\begin{array}{c}0.116 \\
56\end{array}$ & $\begin{array}{c}0.161 \\
56\end{array}$ & $\begin{array}{c}-0.113 \\
56\end{array}$ & $\begin{array}{c}-0.186 \\
56\end{array}$ & $\begin{array}{c}0.129 \\
56\end{array}$ & $\begin{array}{c}0.079 \\
56\end{array}$ & $\begin{array}{c}0.036 \\
56\end{array}$ & $\begin{array}{c}0.156 \\
56\end{array}$ & $\begin{array}{c}1 \\
56\end{array}$ & \\
\hline $\begin{array}{l}\text { Reorganization activities } \\
\text { N }\end{array}$ & $\begin{array}{c}0.008 \\
56\end{array}$ & $\begin{array}{c}0.051 \\
56\end{array}$ & $\begin{array}{l}-0.052 \\
56\end{array}$ & $\begin{array}{l}-0.030 \\
56\end{array}$ & $\begin{array}{ll}0.264^{*} \\
56\end{array}$ & $\begin{array}{c}0.152 \\
56\end{array}$ & $\begin{array}{c}0.116 \\
56\end{array}$ & $\begin{array}{l}-0.068 \\
56\end{array}$ & $\begin{array}{l}0.297^{*} \\
56\end{array}$ & $\begin{array}{l}0.147 \\
56\end{array}$ & $\begin{array}{l}-0.100 \\
56\end{array}$ & $\begin{array}{c}-0.048 \\
56\end{array}$ & $\begin{array}{c}0.173 \\
56\end{array}$ & $\begin{array}{c}1 \\
56\end{array}$ \\
\hline
\end{tabular}

Notes: ** Significant at 0.01 level; * significant at 0.05 level. 
Table 31. OG Pearson correlations.

\begin{tabular}{|c|c|c|c|c|c|c|c|c|c|c|c|c|c|c|}
\hline \multicolumn{15}{|c|}{ Old Generation } \\
\hline & $\begin{array}{c}\text { Italian } \\
\text { Customers }\end{array}$ & $\begin{array}{c}\text { Foreign } \\
\text { Customers }\end{array}$ & $\begin{array}{l}\text { Young } \\
\text { Customers }\end{array}$ & $\begin{array}{l}\text { "Families" } \\
\text { Customers }\end{array}$ & $\begin{array}{l}\text { Over } 65 \\
\text { Customers }\end{array}$ & $\begin{array}{c}\text { Family } \\
\text { Members } \\
\text { Involved in } \\
\text { Agritourism }\end{array}$ & $\begin{array}{c}\text { Role of } \\
\text { Family } \\
\text { Members } \\
\text { within } \\
\text { Agritourism }\end{array}$ & $\begin{array}{l}\text { Gender } \\
\text { Diversity }\end{array}$ & $\begin{array}{l}\text { Non-family } \\
\text { Members } \\
\text { Involved in } \\
\text { Agritourism }\end{array}$ & $\begin{array}{c}\text { Average } \\
\text { Turnover of } \\
\text { the Last } \\
\text { Three Years }\end{array}$ & $\begin{array}{c}\text { Average } \\
\text { Annual Costs } \\
\text { of the Last } \\
\text { Three Years }\end{array}$ & $\begin{array}{l}\text { Financing } \\
\text { Sources }\end{array}$ & $\begin{array}{c}\text { Investment } \\
\text { in Activities } \\
\text { to Increase } \\
\text { Customer } \\
\text { Loyalty }\end{array}$ & $\begin{array}{l}\text { Reorganization } \\
\text { Activities }\end{array}$ \\
\hline $\begin{array}{c}\text { Italian Customers } \\
\mathrm{N}\end{array}$ & $\begin{array}{c}1 \\
54\end{array}$ & & & & & & & & & & & & & \\
\hline $\begin{array}{c}\text { Foreign customers } \\
\mathrm{N}\end{array}$ & $\begin{array}{l}-0.704 * * \\
54\end{array}$ & $\begin{array}{c}1 \\
54\end{array}$ & & & & & & & & & & & & \\
\hline $\begin{array}{c}\text { Young customers } \\
\mathrm{N}\end{array}$ & $\begin{array}{l}0.271^{*} \\
54\end{array}$ & $\begin{array}{c}-0.154 \\
54\end{array}$ & $\begin{array}{c}1 \\
54\end{array}$ & & & & & & & & & & & \\
\hline $\begin{array}{c}\text { "Families" customers } \\
\text { N }\end{array}$ & $\begin{array}{c}0.071 \\
54\end{array}$ & $\begin{array}{c}0.073 \\
54\end{array}$ & $\begin{array}{l}-0.381^{* *} \\
54\end{array}$ & $\begin{array}{c}1 \\
54\end{array}$ & & & & & & & & & & \\
\hline $\begin{array}{c}\text { Over } 65 \text { customers } \\
\mathrm{N}\end{array}$ & $\begin{array}{c}-0.080 \\
54\end{array}$ & $\begin{array}{c}0.135 \\
54\end{array}$ & $\begin{array}{c}-0.319 * \\
54\end{array}$ & $\begin{array}{l}-0.604 * * \\
54\end{array}$ & $\begin{array}{c}1 \\
54\end{array}$ & & & & & & & & & \\
\hline $\begin{array}{c}\text { Family members involved } \\
\text { in agritourism } \\
\mathrm{N}\end{array}$ & $\begin{array}{c}0.073 \\
54\end{array}$ & $\begin{array}{c}0.127 \\
54\end{array}$ & $\begin{array}{c}0.061 \\
54\end{array}$ & $\begin{array}{c}0.041 \\
54\end{array}$ & $\begin{array}{c}0.098 \\
54\end{array}$ & $\begin{array}{c}1 \\
54\end{array}$ & & & & & & & & \\
\hline $\begin{array}{l}\text { Role of family members } \\
\text { within agritourism } \\
\mathrm{N}\end{array}$ & $\begin{array}{c}-0.203 \\
54\end{array}$ & $\begin{array}{c}0.120 \\
54\end{array}$ & $\begin{array}{c}-0.032 \\
54\end{array}$ & $\begin{array}{c}0.183 \\
54\end{array}$ & $\begin{array}{c}-0.222 \\
54\end{array}$ & $\begin{array}{c}0.202 \\
54\end{array}$ & $\begin{array}{c}1 \\
54\end{array}$ & & & & & & & \\
\hline $\begin{array}{c}\text { Gender diversity } \\
\mathrm{N}\end{array}$ & $\begin{array}{l}0.058 \\
54\end{array}$ & $\begin{array}{l}-0.108 \\
54\end{array}$ & $\begin{array}{c}-0.072 \\
54\end{array}$ & $\begin{array}{l}-0.026 \\
54\end{array}$ & $\begin{array}{c}0.066 \\
54\end{array}$ & $\begin{array}{l}-0.294 * \\
54\end{array}$ & $\begin{array}{l}-0.295 * \\
54\end{array}$ & $\begin{array}{c}1 \\
54\end{array}$ & & & & & & \\
\hline $\begin{array}{c}\text { Non-family members } \\
\text { involved in agritourism } \\
\mathrm{N} \\
\end{array}$ & $\begin{array}{c}0.037 \\
54\end{array}$ & $\begin{array}{c}-0.018 \\
54\end{array}$ & $\begin{array}{c}0.160 \\
54 \\
\end{array}$ & $\begin{array}{c}-0.176 \\
54 \\
\end{array}$ & $\begin{array}{c}0.091 \\
54 \\
\end{array}$ & $\begin{array}{c}0.375 \text { ** } \\
54 \\
\end{array}$ & $\begin{array}{c}0.102 \\
54\end{array}$ & $\begin{array}{c}-0.364 \\
* * \\
54 \\
\end{array}$ & $\begin{array}{c}1 \\
54 \\
\end{array}$ & & & & & \\
\hline $\begin{array}{l}\text { Average turnover of the } \\
\text { last three years } \\
\text { N }\end{array}$ & $\begin{array}{c}0.119 \\
54\end{array}$ & $\begin{array}{c}-0.127 \\
54\end{array}$ & $\begin{array}{c}0.090 \\
54\end{array}$ & $\begin{array}{c}-0.077 \\
54\end{array}$ & $\begin{array}{c}0.063 \\
54\end{array}$ & $\begin{array}{c}0.421 \text { ** } \\
54\end{array}$ & $\begin{array}{c}0.154 \\
54\end{array}$ & $\begin{array}{c}-0.261 \\
54\end{array}$ & $\begin{array}{c}0.770^{* *} \\
54\end{array}$ & $\begin{array}{c}1 \\
54\end{array}$ & & & & \\
\hline $\begin{array}{c}\text { Average annual costs of } \\
\text { the last three years } \\
\mathrm{N}\end{array}$ & $\begin{array}{c}-0.068 \\
54\end{array}$ & $\begin{array}{c}0.138 \\
54\end{array}$ & $\begin{array}{c}0.175 \\
54\end{array}$ & $\begin{array}{c}-0.050 \\
54\end{array}$ & $\begin{array}{c}-0.062 \\
54\end{array}$ & $\begin{array}{c}0.257 \\
54\end{array}$ & $\begin{array}{c}0.116 \\
54\end{array}$ & $\begin{array}{c}-0.013 \\
54\end{array}$ & $\begin{array}{c}0.307^{*} \\
54\end{array}$ & $\begin{array}{c}0.205 \\
54\end{array}$ & $\begin{array}{c}1 \\
54\end{array}$ & & & \\
\hline $\begin{array}{c}\text { Financing sources } \\
\mathrm{N}\end{array}$ & $\begin{array}{l}0.103 \\
54\end{array}$ & $\begin{array}{c}0.053 \\
54\end{array}$ & $\begin{array}{c}-0.114 \\
54\end{array}$ & $\begin{array}{l}-0.081 \\
54\end{array}$ & $\begin{array}{c}0.229 \\
54\end{array}$ & $\begin{array}{c}-0.014 \\
54\end{array}$ & $\begin{array}{c}-0.059 \\
54\end{array}$ & $\begin{array}{l}0.107 \\
54\end{array}$ & $\begin{array}{l}-0.038 \\
54\end{array}$ & $\begin{array}{c}0.093 \\
54\end{array}$ & $\begin{array}{c}-0.074 \\
54\end{array}$ & $\begin{array}{c}1 \\
54\end{array}$ & & \\
\hline $\begin{array}{l}\text { Investment in activities to } \\
\text { increase customer loyalty } \\
\text { N }\end{array}$ & $\begin{array}{c}-0.137 \\
54\end{array}$ & $\begin{array}{c}0.123 \\
54\end{array}$ & $\begin{array}{l}-0.489 * * \\
54\end{array}$ & $\begin{array}{c}0.226 \\
54\end{array}$ & $\begin{array}{c}0.153 \\
54\end{array}$ & $\begin{array}{c}0.047 \\
54\end{array}$ & $\begin{array}{c}0.029 \\
54\end{array}$ & $\begin{array}{c}0.029 \\
54\end{array}$ & $\begin{array}{c}0.118 \\
54\end{array}$ & $\begin{array}{c}0.059 \\
54\end{array}$ & $\begin{array}{c}0.091 \\
54\end{array}$ & $\begin{array}{c}0.112 \\
54\end{array}$ & $\begin{array}{c}1 \\
54\end{array}$ & \\
\hline $\begin{array}{l}\text { Reorganization activities } \\
\text { N }\end{array}$ & $\begin{array}{c}0.243 \\
54\end{array}$ & $\begin{array}{c}-0.172 \\
54\end{array}$ & $\begin{array}{l}0.247 \\
54\end{array}$ & $\begin{array}{c}-0.154 \\
54\end{array}$ & $\begin{array}{c}0.068 \\
54\end{array}$ & $\begin{array}{c}0.061 \\
54\end{array}$ & $\begin{array}{c}0.115 \\
54\end{array}$ & $\begin{array}{c}0.243 \\
54\end{array}$ & $\begin{array}{c}0.075 \\
54\end{array}$ & $\begin{array}{c}0.249 \\
54\end{array}$ & $\begin{array}{c}0.146 \\
54\end{array}$ & $\begin{array}{c}0.178 \\
54\end{array}$ & $\begin{array}{c}-0.022 \\
54\end{array}$ & $\begin{array}{c}1 \\
54\end{array}$ \\
\hline
\end{tabular}

Notes: ** Significant at 0.01 level; * significant at 0.05 level. 


\section{Conclusions and Future Research}

Analyzing one of the main Italian regions, the Piedmont, where the agritourism business is a developing phenomenon, it was possible to identify the key factors that enable the sustainable value creation for these kinds of organizations, basing the research on a sample of agritourism businesses.

Analyzing the BMs of agritourism in the Piedmont, it emerged as a key activity the offering of complementary products and restaurant services and it emerged that rural culture and tourists' mutual engagement were critical for agribusiness to integrate the specific characteristics of internal service [54].

Generally, the internal employees are recognized as key partners and key resources; they support the core business and the key activities. The employees mainly belong to the family; they are limited in number, and show a prevalence of the female gender. Empirical evidence shows that the number of generations involved in agritourism is positively correlated with the presence of family members. However, a relevant finding underlines a positive relation between the average turnover of the last three years with the non-family members involved in running business. This evidence is also confirmed by the linear regression, suggesting that the ownership may enlarge the staff involving external members in order to improve the dimension of the business. This is also supported by the study conducted by Hung [55], which affirms that the quantity and quality of human resources are key success factors for mid- and high-performance agritourism.

Another key factor is represented by the financing sources, mainly characterized by the family investments, showing the will to strengthen the economic development and support the durability of the business.

In supporting agritourism, the main costs are strictly tied to raw materials and fixed assets, even if generating a limited turnover. Empirical evidence highlights a positive correlation between the average costs of the last three years with the non-family members involved and with the average turnover of the last three years. In this way, increasing staff with external members, the operating costs increase, but so does the company turnover.

To improve value proposition, some actions of reorganization have been implemented, generating customer satisfaction and an increase in efficiency. In addition, a moderate correlation between reorganization activities and average turnover of the last three years was highlighted, pushing towards a business reengineering approach.

Finally, the agritourism businesses are aware of their customer segmentation, showing an equal distribution among Italian, foreign, young, families and clients over 65. Furthermore, empirical implications show a strong correlation between young customers, with an age between 18 and 35 years old, and the Italian nationality and a moderate correlation between customers over 65 and foreign customers.

Under a sustainability perspective, according to Schaltegger et al. [16] and Barbieri [32], deepening the three pillars, it emerges that:

from the economic point of view, there is an ability to optimize the direct and operating cost, especially by self-producing the raw material goods, preserving the natural environment and the wellbeing of the local community. However, the limited turnover clusters agritourism as small businesses. The small dimension should not be interpreted in negative terms, as it enables strengthening of the link with the territory, preserving cultural and product heritage. The ability to attract customers contributes not only to the economic growth of the company, but also to the local economy. In addition, a financial virtuous circle is created due to a relevant self-financing;

- from the sociocultural point of view, there is a strong link with the territory, highlighted by the offering of one's own agricultural products. In this way, it is possible to increase the wellbeing of rural families, contributing to the employment of family members and future generations, and also of non-family members, attracting youth in rural communities; 
- from the environmental point of view, the offer of ecotourism activities strengthens the preservation of the rural landscape, and can sensitize customers to preserve nature. In addition, the companies' behaviour represented by recycling habits and the short supply chain shows the attention to safeguard the environment.

In addition, the study highlights the presence of two different groups of BMs, based on the number of successive generations in agritourism: the NG group and the OG group. In particular, observing the 9 key success factors integrated with a sustainability perspective, some differences arose between the NG and the OG. It seems that OG is more inclined toward sustainability practices, while NG stresses more attention on obtaining quality standards and certifications. This evidence emerges, in particular, by the activities carried out and by the main value proposition elements. NG attracts more foreign customers, while OG attracts a national clientele of families and those over 65 , underlining a greater link with the local community.

It is possible to affirm that the agritourism business model generally plays a critical role in determining performance [55].

Practical implications could be addressed to implement adequate policies for the development of agritourism as an instrument for the sustainability of the rural community. In this way, the communication of the key factors to attract more customers could be more effective. Furthermore, this tourism form is not perceived as the prerogative of a particular market segment as it attracts both families with or without children as well as young people traveling in groups [56,57]. In addition, an ecologically and socially inclusive model of agritourism is put forward based on principles of sustainable; agroecological tourism strengthens the linkages between tourism and agriculture while fostering sustainability principles. [58].

From the theoretical point of view, this study contributes to the national and international debate on peculiarities of agritourism, trying to bridge the gap highlighted by Barbieri [32], especially under the sustainability dimensions.

Future research could involve other Italian Regions in order to expand the sample of analysis and better understand the meaning of key factors for sustainable value creation.

Author Contributions: These authors contributed equally to this paper.

Conflicts of Interest: The authors declare no conflict of interest.

\section{References}

1. Frochot, I. A benefit segmentation of tourists in rural areas: A Scottish perspective. Tour. Manag. 2005, 26, 335-346. [CrossRef]

2. Van Huylenbroeck, G.; Vanslembrouck, I.; Calus, M.; Van de Velde, L. Synergies between farming and rural tourism: Evidence from Flanders. EuroChoices 2006, 5, 14-21. [CrossRef]

3. Arroyo, C.G.; Barbieri, C.; Rich, S.R. Defining agritourism: A comparative study of stakeholders' perceptions in Missouri and North Carolina. Tour. Manag. 2013, 37, 39-47. [CrossRef]

4. Sonnino, R. For a 'piece of bread'? Interpreting sustainable development through agritourism in Southern Tuscany. Sociol. Ruralis 2004, 44, 285-300. [CrossRef]

5. Esposti, R.; Pierani, P. Price, private demand and optimal provision of public R\&D investment: An application to Italian agriculture, 1960-1995. Empir. Econ. 2006, 31, 699-715.

6. Santucci, F. Agritourism for rural development in Italy; evolution, situation and perspectives. Br. J. Econ. Manag. Trade 2013, 3, 186-200. [CrossRef]

7. Lupi, C.; Giaccio, V.; Mastronardi, L.; Giannelli, A.; Scardera, A. Exploring the features of agritourism and its contribution to rural development in Italy. Land Use Policy 2017, 64, 383-390. [CrossRef]

8. Sidali, K.L.; Spiller, A.; Schulze, B. (Eds.) Food, Agri-Culture and Tourism: Linking Local Gastronomy and Rural Tourism: Interdisciplinary Perspectives; Springer Science Business Media: New York, NY, USA, 2011.

9. Tew, C.; Barbieri, C. The perceived benefits of agritourism: The provider's perspective. Tour. Manag. 2012, 33, 215-224. [CrossRef] 
10. Normann, R.; Ramirez, R. From value chain to value constellation: Designing interactive strategy. Harv. Bus. Rev. 1992, 71, 65-77.

11. Parolini, C. The Value Net: A Tool for Competitive Strategy; Wiley: Hoboken, NJ, USA, 1999.

12. Massa, L.; Tucci, C.L. Business Model Innovation. In The Oxford Handbook of Innovafion Management; Oxford University Press: New York, NY, USA, 2013; pp. 420-441.

13. Chesbrough, H. Business model innovation: Opportunities and barriers. Long Range Plan. 2010, 43, 354-363. [CrossRef]

14. Choo, H. Agritourism: Development and Research. J. Tour. Res. Hosp. 2012, 1. [CrossRef]

15. Osterwalder, A. The Business Model Ontology-A Proposition in a Design Science Approach. Ph.D. Dissertation, University of Lausanne, Lausanne, Switzerland, 2004.

16. Schaltegger, S.; Hansen, E.G.; Lüdeke-Freund, F. Business models for sustainability: Origins, present research, and future avenues. Organ. Environ. 2015, 29, 3-10. [CrossRef]

17. Istat. 2016. Available online: https://www.istat.it/it/archivio/198686 (accessed on 3 May 2017).

18. Phillip, S.; Hunter, C.; Blackstock, K. A typology for defining agritourism. Tour. Manag. 2010, 31, 754-758. [CrossRef]

19. Organisation for Economic Co-operation and Development (OECD). Agricultural Policies of the OECD Countries: Monitoring and Evaluation; OECD Publishing: Paris, France, 2001.

20. United States Department of Agriculture (USDA). Agricultural Statistics. 2009. Available online: https: / / www.nass.usda.gov / Publications/Ag_Statistics/2009/ (accessed on 3 May 2017).

21. Carpio, C.E.; Wohlgenant, M.K.; Boonsaeng, T. The demand for agritourism in the United States. J. Agric. Resour. Econ. 2008, 33, 254-269.

22. National Framework for Agritourism. 1985. Available online: http://www.coldiretti.it/organismi/ Verdimpresa/Strumenti_finanziari/nazionali/agriturismo_legge_quadro.htm (accessed on 30 March 2017).

23. Flanigan, S.; Blackstock, K.; Hunter, C. Agritourism from the perspective of providers and visitors: A typology-based study. Tour. Manag. 2014, 40, 394-405. [CrossRef]

24. Zheng, J.X. Development of tourist and recreational agriculture and rural tourism in mainland China and Taiwan. In Economic Analysis on Recreational Agriculture; Guo, H.C., Zheng, J.X., Eds.; China University of Mining and Technology Press: Xuzhou, China, 2004; pp. 71-85. (In Chinese)

25. Zott, C.; Amit, R.; Massa, L. The business model: Recent developments and future research. J. Manag. 2011, 37, 1019-1042.

26. Lowitt, E. The Collaboration Economy: How to Meet Business, Social, and Environmental Needs and Gain Competitive Advantage; John Wiley \& Sons: Hoboken, NJ, USA, 2013.

27. Bocken, N.M.P.; Short, S.W.; Rana, P.; Evans, S. A literature and practice review to develop sustainable business model archetypes. J. Clean. Prod. 2014, 65, 42-56. [CrossRef]

28. Osterwalder, A.; Pigneur, Y.; Tucci, C.L. Clarifying business models: Origins, present, and future of the concept. Commun. Assoc. Inf. Syst. 2005, 16, 1.

29. Osterwalder, A.; Pigneur, Y. Business Model Generation: A Handbook for Visionaries, Game Changers, and Challengers; John Wiley \& Sons: Hoboken, NJ, USA, 2010.

30. Scaglione, A.; Mendola, D. Measuring the perceived value of rural tourism: A field survey in the western Sicilian agritourism sector. Qual. Quant. 2017, 51, 745-763. [CrossRef]

31. Barbieri, C.; Tew, C. Perceived impact of agritourism on farm economic standing, sales and profits. In Proceedings of the 2010 Travel and Tourism Research Association Conference, San Antonio, TX, USA, 20-22 June 2010.

32. Barbieri, C. Assessing the Sustainability of Agritourism in the US: A comparison between agritourism and other farm entrepreneurial ventures. J. Sustain. Tour. 2013, 21, 252-270. [CrossRef]

33. Mcghee, N.G.; Kim, K. Motivation for agri-tourism entrepreneurship. J. Travel Res. 2004, 43, 161-170. [CrossRef]

34. Ollenburg, C.; Buckley, R. Stated economic and social motivations of farm tourism operators. J. Travel Res. 2007, 45, 444-452. [CrossRef]

35. Gnyawali, D.R.; Fogel, D.S. Environments for entrepreneurship development: Key dimensions and research implications. Entrep. Theory Pract. 1994, 18, 43.

36. Match, M.J. Organization Theory; Modern, Symbolic, and Postmodern Perspective; Oxford University Press: New York, NY, USA, 1997. 
37. Miner, J.B. Organizational Behavior 1: Essential Theories of Motivation and Leadership; Routledge: London, UK, 2015.

38. Doh, J.; Rodrigues, S.; Saka-Helmhout, A.; Makhija, M. International Business Responses to Institutional Voids. J. Int. Bus. Stud. 2017, 48, 293-307. [CrossRef]

39. Lane, B. Sustainable rural tourism strategies: A tool for development and conservation. J. Sustain. Tour. 1994, 2, 102-111. [CrossRef]

40. World Tourism Organization. 2009. Available online: http://www.e-unwto.org/doi/pdf/10.18111/ 9789284413720 (accessed on 5 April 2017).

41. World Tourism Organization. 2015. Available online: http://www2.unwto.org/publication/unwto-annualreport-2015 (accessed on 5 April 2017).

42. Butler, R.W. Sustainable tourism: A state-of-the-art review. Tour. Geogr. 1999, 1, 7-25. [CrossRef]

43. Saarinen, J. Traditions of sustainability in tourism studies. Ann. Tour. Res. 2006, 33, 1121-1140. [CrossRef]

44. Swarbrooke, J. Sustainable Tourism Management; CABI Publishing: Wallingford, UK, 1999.

45. Carlsen, J.; Getz, D.; Ali-Knight, J. The environmental attitudes and practices of family businesses in the rural tourism and hospitality sectors. J. Sustain. Tour. 2001, 9, 281-297. [CrossRef]

46. Choo, H.; Jamal, T. Tourism on organic farms in South Korea: A new form of ecotourism? J. Sustain. Tour. 2009, 17, 431-454. [CrossRef]

47. Smit, B.; Brklacich, M. Sustainable development and the analysis of rural systems. J. Rural Stud. 1989, 5, 405-414. [CrossRef]

48. Boons, F.; Lüdeke-Freund, F. Business models for sustainable innovation: State-of-the-art and steps towards a research agenda. J. Clean. Prod. 2013, 45, 9-19. [CrossRef]

49. Andereck, K.L.; Valentine, K.M.; Vogt, C.A.; Knopf, R.C. A cross-cultural analysis of tourism and quality of life perceptions. J. Sustain. Tour. 2007, 15, 483-502. [CrossRef]

50. Bramwell, B.; Alletorp, L. Attitudes in the Danish tourism industry to the roles of business and government in sustainable tourism. Int. J. Tour. Res. 2001, 3, 91-103. [CrossRef]

51. Budeanu, A. Impacts and responsibilities for sustainable tourism: A tour operator's perspective. J. Clean. Prod. 2005, 13, 89-97. [CrossRef]

52. Stoddard, E.; Evans, M.R.; Davé, D.S. Sustainable tourism: The case of the Blue Ridge National Heritage Area. Cornell Hosp. Q. 2008, 49, 245-257. [CrossRef]

53. Tavitiyaman, P.; Qiu Zhang, H.; Qu, H. The effect of competitive strategies and organizational structure on hotel performance. Int. J. Contemp. Hosp. Manag. 2012, 24, 140-159. [CrossRef]

54. Rong-Da Liang, A. Considering the role of agritourism co-creation from a service-dominant logic perspective. Tour. Manag. 2017, 61, 354-367. [CrossRef]

55. Hung, W.T.; Ding, H.Y.; Lin, S.T. Determinants of performance for agritourism farms: An alternative approach. Curr. Issues Tour. 2016, 19, 1281-1287. [CrossRef]

56. Cambi, C. Gli Italiani e le vacanze in Agriturismo. Presented at the Agri\&tour, Arezzo, Italy, 17-18 November 2006.

57. Surdo, G.L. Agriturismo: Risorse, Gestione, Programmazione, Esperienze; Edagricole: Bologna, Italy, 1988.

58. Addinsall, C.; Scherrer, P.; Weiler, B.; Glencross, K. An ecologically and socially inclusive model of agritourism to support smallholder livelihoods in the South Pacific. Asia Pac. J. Tour. Res. 2017, 22, 301-315. [CrossRef]

(C) 2017 by the authors. Licensee MDPI, Basel, Switzerland. This article is an open access article distributed under the terms and conditions of the Creative Commons Attribution (CC BY) license (http:/ / creativecommons.org/licenses/by/4.0/). 